Corps ers

Waterways Experiment

Station

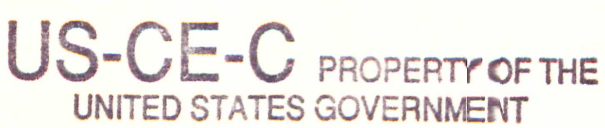

Long-Term Effects of Dredging Operations Program

\title{
Chronic Sublethal Effects of San Francisco Bay Sediments on Nereis (Neanthes) arenaceodentata; Interpretative Guidance for a Growth End Point
}

\author{
by David W. Moore, Thomas M. Dillon \\ Environmental Laboratory
}

Approved For Public Release; Distribution Is Unlimited

RESEARCH LIBRARY

US ARMY ENGINEER WATERWAYS

EXPERIMENT STATION

VICKSBURG, MISSISSIPPI

Prepared for Headquarters, U.S. Army Corps of Engineers and U.S. Army Engineer District, San Francisco 


\section{Chronic Sublethal Effects of San Francisco Bay Sediments on Nereis (Neanthes) arenaceodentata; Interpretative Guidance for a Growth End Point}

by David W. Moore, Thomas M. Dillon

Environmental Laboratory

U.S. Army Corps of Engineers

Waterways Experiment Station

3909 Halls Ferry Road

Vicksburg, MS 39180-6199

Final report

Approved for public release; distribution is unlimited

Prepared for U.S. Army Corps of Engineers

Washington, DC 20314-1000

and U.S. Army Engineer District, San Francisco

San Francisco, CA 94105-1905 


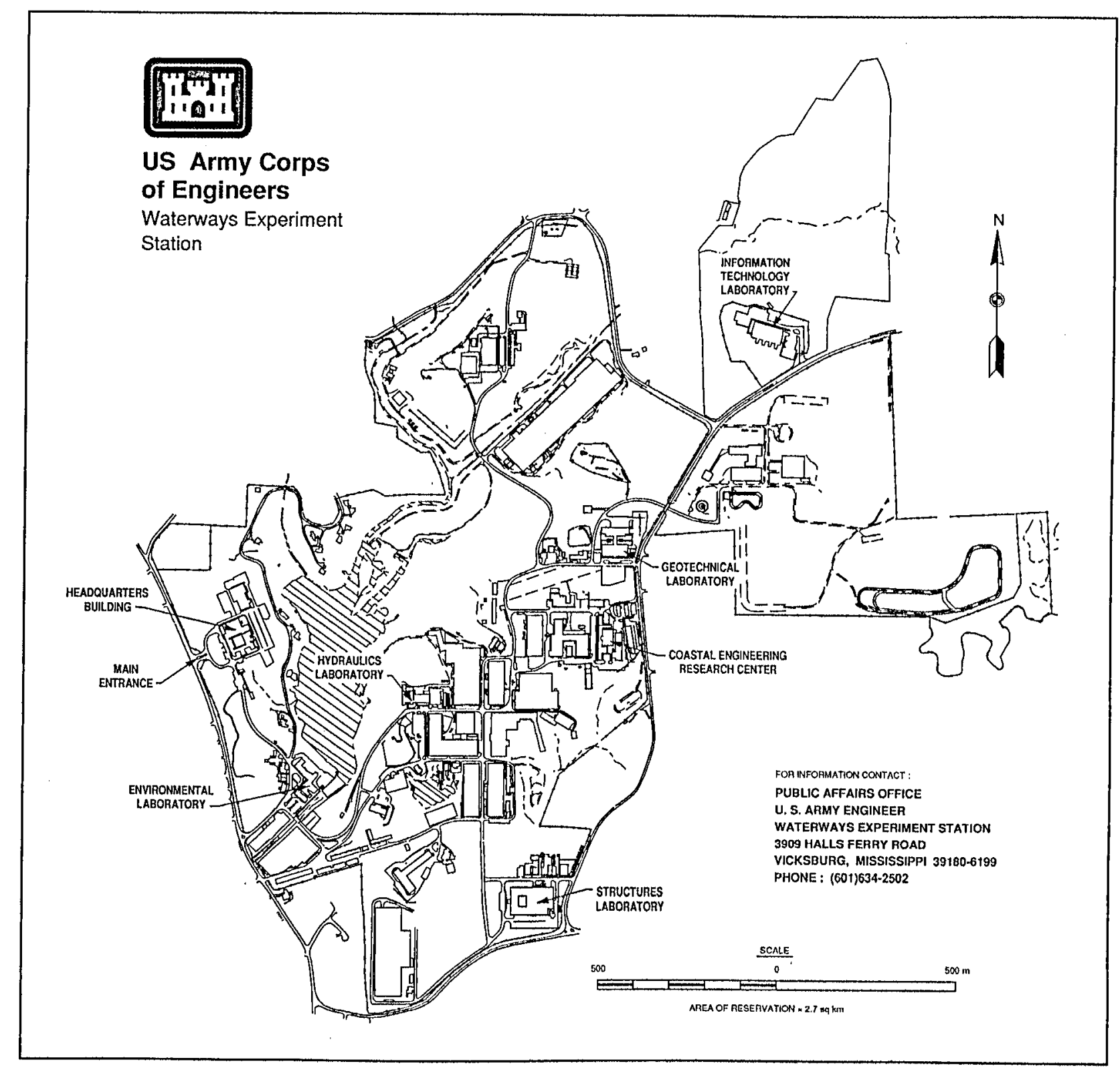

\section{Waterways Experiment Station Cataloging-In-Publication Data}

Moore, David W.

Chronic sublethal effects of San Francisco Bay sediments on Nereis (Neanthes) arenaceodentata : interpretative guidance for a growth end point / by David W. Moore, Thomas M. Dillon ; prepared for U.S. Army Corps of Engineers and U.S. Army Engineer District, San Francisco.

38 p. : ill. ; $28 \mathrm{~cm}$. - (Miscellaneous paper ; D-93-5) Includes bibliographical references.

1. Marine sediments - California - San Francisco Bay. 2. Dredging spoil - California - San Francisco Bay - Testing. 3. Nereis Growth - Effect of pollution on. 4. Biological assay. I. Dillon, Thomas M. II. United States. Army. Corps of Engineers. III. United States. Army. Corps of Engineers. San Francisco District. IV. U.S. Army Engineer Waterways Experiment Station. V. Long-Term Effects of Dredging Operations Program (U.S.) VI. Title. VII. Series: Miscellaneous paper (U.S. Army Engineer Waterways Experiment Station) ; D-93-5.

TA7 W34m no.D-93-5 


\section{Contents}

Preface $\ldots \ldots \ldots \ldots \ldots \ldots \ldots \ldots \ldots \ldots$

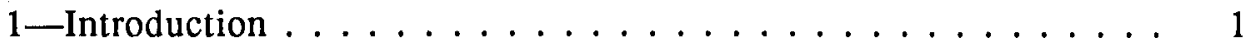

Background . . . . . . . . . . . . . . . . 1

Regulatory History of Dredged Material Management in San Francisco Bay . . . . . . . . . . . . . . . 2

Overview of Sediment Toxicity Test Development in the United States . . . . . . . . . . . . . . . 4

Scope ...................... 7

2-Material and Methods $\ldots \ldots \ldots \ldots \ldots \ldots$

Test Species . . . . . . . . . . . . . . . . . 10

Laboratory Cultures $\ldots \ldots \ldots \ldots \ldots \ldots \ldots \ldots \ldots$

Juvenile Growth . . . . . . . . . . . . . . . . . . 12

Growth-Reproduction Relationship . . . . . . . . . . 12

Data Analysis . . . . . . . . . . . . . . . . . . 13

$3-$ Results $\ldots \ldots \ldots \ldots \ldots \ldots \ldots \ldots \ldots \ldots \ldots$

Juvenile Growth . . . . . . . . . . . . . . . . . . 17

Growth-Reproduction Relationship . . . . . . . . . . . 17

4-Discussion . . . . . . . . . . . . . . . . 22

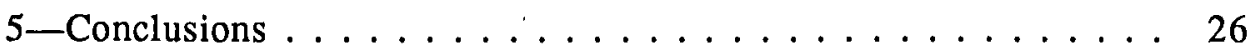

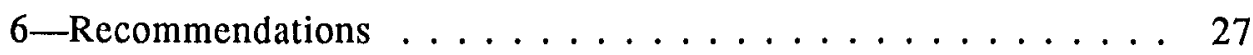

References . . . . . . . . . . . . . . . . . 28

SF 298

\section{List of Figures}

Figure 1. Sublethal end points within levels of biological organization . . . . . . . . . . 8 
Figure 2. Experimental timetable for exposure of $N$. arenaceodentata to a food ration gradient . . . . .

Figure 3. Mean individual dry weights of $N$. arenaceodentata measured at weekly intervals over a 12 -week period . . .

Figure 4. Percent survival of $N$. arenaceodentata after 9 weeks on reduced food rations . . . . . . . . . . 15

Figure 5. Mean individual wet weights of $N$. arenaceodentata after 3,6 , and 9 weeks on reduced food rations . . . . . 16

Figure 6. Fecundity in $N$. arenaceodentata after 9 weeks on reduced food rations . . . . . . . . . 16

Figure 7. EJ production in $N$. arenaceodentata after 9 weeks on reduced food rations . . . . . . . . . . 20

Figure 8. Mean time between reproductive events in $N$. arenaceodentata after a 9-week exposure

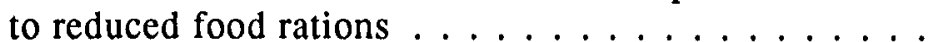

\section{List of Tables}

Table 1. Milestones in the Regulation of Dredged Material in San Francisco Bay . . . . . . . . . . . . . 3

Table 2. Milestones in Scientific Development of Sediment Toxicity Tests . . . . . . . . . . . 5

Table 3. Effect of Reduced Food Ration on Survival, Individual Worm Growth, and Reproduction

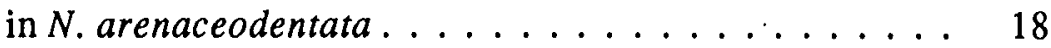

Table 4. Effect of Reduced Food Ration on Somatic Growth Rate in N. arenaceodentata . . . . . . . . . 23 


\section{Preface}

The work reported herein was conducted by the U.S. Army Engineer Waterways Experiment Station (WES) for the U.S. Army Engineer District (USAED), San Francisco, and for Headquarters, U.S. Army Corps of Engineers (HQUSACE). Financial support was provided by the USAED, San Francisco, through an Intra-Army Order for Reimbursable Services. Additional funding was provided by HQUSACE through the Long-Term Effects of Dredging Operations (LEDO) Program, Work Unit 374-9 "Chronic Sublethal Effects." The LEDO Program is managed through the Environmental Effects of Dredging Programs, Dr. R. M. Engler, Manager.

This report was prepared by Drs. David W. Moore and Thomas M. Dillon of the Environmental Processes and Effects Division (EPED), Environmental Laboratory (EL), WES. The authors gratefully acknowledge the support provided by Mr. Thomas Chase, Mr. Carry Guy, Ms. Sandra Lemlich, Mr. Duke Roberts, Dr. Thomas Wakeman, and Mr. Brian Walls of the San Francisco District.

The work was performed under the general supervision of Dr. Bobby L. Folsom, Jr., Chief, Fate and Effects Branch. The Chief of EPED was Mr. Donald L. Robey, and Director of EL was Dr. John Harrison.

At the time of publication of this report, Director of WES was Dr. Robert W. Whalin. Commander was COL Bruce K. Howard, EN.

This report should be cited as follows:

Moore, D. W., and Dillon, T. M. (1993). "Chronic sublethal effects of San Francisco Bay sediments on the polychaete Nereis (Neanthes) arenaceodentata; Interpretative guidance for a growth end point," Miscellaneous Paper D-93-5, U.S. Army Engineer Waterways Experiment Station, Vicksburg, MS. 


\section{Introduction}

\section{Background}

San Francisco Bay is a highly altered estuary. Two of the major reasons are the diversion of freshwater inflow from the Sacramento-San Joaquin River systems and the loss of wetlands. By 1980, the amount of fresh water flowing into San Francisco Bay had been reduced by 60 percent. This reduction is projected to increase an additional 10 percent by the year 2000. About 95 percent of all freshwater/estuarine marshlands had been lost to land reclamation before 1850. It is not surprising, therefore, that the estuary has experienced a general decline in health and viability. One of the more noticeable symptoms of this decline has been the gradual loss of biological resources such as the striped bass and Pacific herring fisheries (Nichols et al. 1986).

An increase in the input of environmental contaminants has accompanied the physical alterations to San Francisco Bay. Major pollutant sources include the freshwater inflow from the Sacramento-San Joaquin River systems, over 50 waste treatment plants, and about 200 industries that are permitted to discharge directly into the Bay (Luoma and Phillips 1988). Environmental contaminants discharged into aqueous systems tend to associate with particulate material in the water column and with bedded sediments. Periodically, bedded sediments must be removed to maintain navigable waterways. There is a concern that the relocation of these dredged materials may be having unacceptable adverse impacts on aquatic biota within the San Francisco Bay.

A large amount of sediment is dredged each year in San Francisco Bay. Approximately 5.5 million cubic meters $(\mathrm{mcm})$ of sediment from Federal projects and permit actions are relocated annually. This value approximates the estimated average annual sediment inflow from natural sources of 6 to $8 \mathrm{mcm}$ (U.S. Army Corps of Engineers (USACE) 1979). It has been estimated that 3.0 to $4.0 \mathrm{mcm}$ of material leaves the Bay annually, while Central and North Bays experience a combined net accumulation of $4.2 \mathrm{mcm}$ (USACE 1979). South Bay shows a net loss of nearly $0.8 \mathrm{mcm}$ per year (Krone 1979). Despite these large numbers, the greatest yearly source of suspended sediment in San Francisco Bay is the resuspension of existing 
bottom material. Approximately 120 to $130 \mathrm{mcm}$ of sediment are resuspended each year by wind waves and currents (USACE 1979). The effect of these resuspended sediments on fish and aquatic invertebrates is unknown.

To examine whether San Francisco Bay dredged material was causing adverse biological effects, the Planning and Engineering Division of the U.S. Army Engineer District, San Francisco, contracted with the Environmental Laboratory of the U.S. Army Engineer Waterways Experiment Station to develop and conduct a series of chronic sublethal sediment bioassays using material from selected sites within the Bay.

\section{Regulatory History of Dredged Material Management in San Francisco Bay}

To help define what is known regarding the potential toxicity of San Francisco Bay sediments, it is useful to first examine how dredged material has been regulated in the past. Important milestones in that process are shown in Table 1. It was recognized very early that San Francisco Bay is a physically dynamic system and that most dredged material disposal sites were dispersive. Consequently, initial management concerns were mostly operational. That is, efforts were directed toward optimizing dredging and disposal operations to minimize transportation costs and redredging.

Passage of the National Environmental Policy Act in 1970 outlined the Federal Government's policy toward the environment and signaled an increasing awareness for environmental protection in this country. That same year the San Francisco District initiated the Dredge Disposal Study (DDS) (USACE 1977). The DDS was a multifaceted interdisciplinary study designed, in part, to address some of the environmental concerns regarding potential impacts of dredge disposal operations. Although sediment toxicity was not examined directly, the physical impacts on biota (USACE 1975a) and the bioaccumulation of contaminants from dredged material were evaluated in laboratory and field studies (USACE 1975b; USACE 1975c). Those studies demonstrated the following:

a. Estuarine animals can survive suspended sediment loads in excess of those normally encountered during dredging and disposal.

b. In laboratory exposures to San Francisco Bay sediments, estuarine animals can bioaccumulate trace contaminants.

c. In field studies, contaminant tissue concentrations in animals near the disposal operations were not different from those far removed. The one exception was slightly elevated $p, p^{\prime}$-DDE concentrations in mussels, Mytilus edulis, during disposal. These differences were not detected 1 month postdisposal. 


\begin{tabular}{|c|c|}
\hline \multicolumn{2}{|c|}{$\begin{array}{l}\text { Table } 1 \\
\text { Milestones in the Regulation of Dredged Material in San Francisco Bay }\end{array}$} \\
\hline 1965 & $\begin{array}{l}\text { Committee on Tidal Hydraulics suggests that San Francisco District (CESPN) may be redredging a } \\
\text { significant amount of material. }\end{array}$ \\
\hline 1970 & Passage of National Environmental Policy Act. \\
\hline 1970 & CESPN initiates Dredge Disposal Study. Terminated in 1975. \\
\hline 1972 & CESPN reduces the number of in-bay disposal sites from 11 to 5 . \\
\hline 1972 & $\begin{array}{l}\text { California RWQCB adopts USEPA's Jensen bulk sediment criteria. Material classified as "polluted" by } \\
\text { these criteria was either placed upland or taken offshore to the } 180 \text {-meter ocean disposal site. }\end{array}$ \\
\hline 1973 & USACE initiates Dredged Material Research Program. Terminated in 1978. \\
\hline 1976 & $\begin{array}{l}\text { USACE publishes interim guidance for implementation of Section 404(b) of Public Law 92-500 (USACE } \\
404 \text { Manual). }\end{array}$ \\
\hline 1977 & Publication of USEPAVUSACE Ocean Disposal Implementation Manual. \\
\hline 1980 & California RWQCB adopts PN 78-1. \\
\hline 1980 & $\begin{array}{l}100 \text {-fathom ocean disposal site becomes part of the Point Reyes-Farallon Islands Marine Sanctuary and is } \\
\text { subsequently removed from the final designation process by USEPA. }\end{array}$ \\
\hline 1982 & Mounding at the Alcatraz site noted in November. \\
\hline 1984 & CESPN implements siurry policy to enhance dispersion during disposal. \\
\hline 1985 & $\begin{array}{l}\text { CESPN establishes the Disposal Management Program (DMP) to find operational solutions to disposal } \\
\text { problems which are environmentally acceptable. }\end{array}$ \\
\hline 1985 & $\begin{array}{l}\text { San Francisco Bar Channel ocean disposal site receives final designation by USEPA. It can receive only } \\
\text { coarse-grained material. }\end{array}$ \\
\hline 1989 & DMP reconfigured to reflect increasing environmental concerns in San Francisco Bay. \\
\hline 1991 & Final revision of USEPAUUSACE Ocean Disposal Implementation Manual. \\
\hline
\end{tabular}

In 1972, the California Regional Water Quality Control Board (RWQCB) adopted the Jensen criteria (Bowden 1977). These numerical criteria were developed by the U.S. Environmental Protection Agency (USEPA) for freshwater sediment in the Great Lakes and classified sediment as highly polluted, moderately polluted, or slightly polluted based on bulk sediment chemistry. As research on dredged material progressed, it became clear that these and other chemically based numerical criteria were technically inadequate because they did not assess either bioaccumulation potential or toxicity. Both assessments were evaluated in bioassay procedures required by the Ocean Disposal Regulations and the Clean Water Act and contained in both the USEPA/USACE Ocean Disposal Implementation Manual (USEPA/USACE 1977) and the USACE 404 Manual (USACE 1976).

The San Francisco District adopted the use of bioassays for evaluating dredged material. Regulatory procedures were outlined in Public Notice (PN) 78-1. Elutriate procedures were emphasized since disposal sites in San Francisco Bay were generally dispersive. PN 78-1 also reduced the 
number of disposal sites from five to three. These were located in the Carquinez Strait, San Pablo Bay, and Alcatraz Island. To facilitate net export out of the Bay, most dredged material was taken to the Alcatraz disposal site.

In 1982, shoaling was noted at the Alcatraz site. As a result of this important development, the San Francisco District took several steps. The District instituted a slurry policy to enhance dispersion during disposal. It greatly reduced the amount of new dredged material taken to the Alcatraz site and even removed 30 tons $(27,200 \mathrm{~kg})$ of construction debris from the site. It monitored the physical configuration of the mound at Alcatraz and found it to be stable after two winter seasons. All of these actions led to the conclusion that the Alcatraz site could not be considered fully dispersive. Since the majority of dredged material in San Francisco Bay was taken to Alcatraz, a reduction in the capacity of that site represented a major impediment to maintenance dredging and to anticipated new work activities. The San Francisco District established the Disposal Management Program (DMP) in 1985 and charged it with finding solutions to the disposal problem.

The DMP was reconfigured in 1989 to address increasing environmental concerns and to reflect the San Francisco District's commitment to a Long-Term Management Strategy for dredged material. In 1991, the Ocean Disposal Implementation Manual was revised to reflect 14 years of regulatory experience and the many scientific advances that had occurred since 1977. The first major application of these procedures is the proposed redredging of Oakland Inner Harbor.

\section{Overview of Sediment Toxicity Test Development in the United States}

As indicated in the foregoing discussion, the regulation of dredged material in San Francisco Bay has taken advantage of scientific advancements that have occurred elsewhere in the United States. To address concerns specific to the potential toxicity of San Francisco Bay sediments, it is important to have some general knowledge of advances in the field of sediment ecotoxicology. The following is not intended to be a comprehensive review per se, rather it is meant to provide the reader an overview of the advances that have occurred over the past 20 years.

The first peer-reviewed journal article that reported an attempt to assess sediment toxicity was published in 1971 by Gannon and Beeton (1971) (Table 2). The laboratory procedures involved exposing amphipods to freshwater dredged material that had been placed in modified milk cartons. In 1973, recognizing the need for a strong technical base in its regulatory program, USACE initiated the Dredged Material Research Program (DMRP). Included in the scope of this large program was the development of elutriate and solid phase bioassays to assess potential water column and benthic 


\begin{tabular}{|c|c|}
\hline \multicolumn{2}{|c|}{$\begin{array}{l}\text { Table } 2 \\
\text { Milestones in Scientific Development of Sediment Toxicity Tests }\end{array}$} \\
\hline 1971 & Gannon and Beeton publish first journal article on sediment bioassays. \\
\hline 1973 & USACE initiates Dredged Material Research Program. Terminated in 1978. \\
\hline 1976 & Publication of Priority Pollutant List by USEPA. \\
\hline 1976 & Publication of USACE 404 Manual. \\
\hline 1977 & Publication of USEPAUUSACE Ocean Disposal Implementation Manual. \\
\hline 1984 & Pellston Conference on Fate and Effect of Sediment-Bound Chemicals. \\
\hline 1987 & Formation of ASTM Subcommittee E47.03 on Sediment Toxicology. \\
\hline 1991 & Final revision of USEPAUUSACE Ocean Disposal Implementation Manual. \\
\hline
\end{tabular}

impacts, respectively (Saucier, Calhoun, and Engler 1978). The bioassays developed during the DMRP were subsequently incorporated into the Ocean Disposal Implementation Manual jointly published by USEPA and USACE in 1977. These sediment bioassays represented a balance between the state of the art and what could be routinely conducted in a regulatory program.

Prior to the mid-1970s, the scientific community expressed relatively little interest in sediment toxicity. Most of their energies were focused on the fate and effects of environmental contaminants dissolved in aqueous solutions. After the Priority Pollutant List was published in 1976, that emphasis shifted for two reasons. First, it was discovered that many chemicals on the Priority Pollutant List were not very water soluble. Second, as more field data were gathered, it became apparent that concentrations of many contaminants on the Priority Pollutant List were much higher in the sediment than in the overlying water. Those findings led to initial speculation that sediments might be extremely toxic. However, subsequent research showed that the same forces causing chemicals to partition into the sediments also restricted their bioavailability to aquatic organisms.

A major milestone marking these scientific advances was the sixth Pellston Conference held in 1984 (Dickson, Maki, and Brungs 1984). This was the first time leaders in the scientific community formally met to discuss the fate and effects of sediment-associated contaminants. Bioassay procedures contained in the 1977 USEPA/USACE Ocean Disposal Implementation Manual formed the basis for initial discussion. The researchers reached consensus regarding sediment toxicity (Anderson et al. 1984). They recognized that species sensitivity was related, in part, to the degree of contact between sediment and organism. They recommended amphipods and mysid shrimp for lethal tests and polychaetes, bivalves, oligochaetes, and fish for behavioral or sublethal tests. There was also a strong endorsement of the Tiered Testing Approach for evaluating contaminated sediments 
(USEPA/USACE 1991). This approach eliminates unnecessary testing and directs limited resources to solving more urgent problems.

Another important milestone in the evolution of sediment toxicity methods occurred in 1987. Members of the American Society for Testing and Materials (ASTM) created a new subcommittee, E47.01 Sediment Toxicology. This subcommittee was charged with identifying technically sound procedures for evaluating sediment toxicity and with drafting appropriate standardized guideline documents. Guidelines, which are in various states of preparation, include the following:

a. Solid Phase Toxicity Tests with Freshwater Invertebrates.

$b$. Solid Phase Toxicity Tests with Marine Amphipods.

c. Solid Phase Toxicity Tests with Marine Polychaetes.

d. Solid Phase Bioaccumulation Tests with Invertebrates.

$e$. Solid Phase Bioaccumulation Tests with Fish.

f. Guidance for Designing Sediment Toxicity Tests.

g. Guidance for Collection, Storage, Characterization, and Manipulation of Sediment Prior to Toxicity Testing.

When the USACE 404 Manual and the USEPA/USACE Ocean Disposal Implementation Manual were first published in 1976 and 1977, respectively, the procedures they contained represented a balance between the state of the art and what could be practically achieved in a routine regulatory testing environment. It was realized at that time that revisions would have to be made to reflect anticipated advances in the scientific community as well as experience gained in regulatory testing programs. The Ocean Disposal Implementation Manual was revised in 1991, and the 404 Manual is currently under revision. Significant improvements to each of these manuals as they relate to sediment toxicity evaluations include the following:

a. Formalizing the Tiered Testing Approach.

$b$. Refinements to the species selection process.

c. Provisions for evaluating chronic sublethal effects.

The assessment of chronic sublethal effects is treated as a Tier IV assessment and would be carried out only if there is a reason to believe chronic impacts may be occurring and if technically sound test protocols are available. 


\section{Scope}

The objective of this report is to provide interpretative guidance for a growth end point in assessing potential toxicity of San Francisco Bay Sediments. In a larger sense, this report is intended to provide input to the District's DMP and Long-Term Management Strategy for dredged material disposal in the San Francisco Bay area.

Test procedures for evaluating potential chronic sublethal effects of dredged material on aquatic biota have not been fully developed. Most suggested protocols have either been water column tests that are ill-adapted for sediment or tests that utilize biological end points with little or no ecological relevance. Before the chronic sublethal effects of San Francisco Bay area sediments can be evaluated in a technically sound manner, a number of issues must be resolved including the following: (a) identification of appropriate test end points, (b) selection of a test organism, (c) development of test protocol, and (d) development of interpretative guidance.

In acute toxicity tests, only one end point is measured, percent survival. In contrast, a plethora of end points exists for sublethal tests. These end points may be categorized according to the level of biological organization they represent. In order of increasing complexity, these levels are as follows: molecular, cellular, tissue, organismic (whole animal), population, and community. When a sublethal effect occurs at any level of biological organization, mechanistic explanations may generally be found at lower levels, while ecological consequences are found at higher levels of complexity.

In the aquatic environment, the ultimate focus of environmental protection is the preservation of viable populations of organisms. Forecasting the potential impact at this level of biological complexity is difficult if not impossible. Bioassessments at lower levels of complexity (moleculartissue) are possible, but their ecological relevance is uncertain. For these reasons, a surrogate toxicological bioassay approach is desirable. This approach, which examines whole animal (organismic) responses, represents a propitious balance between response sensitivity in the sublethal end point and ecological relevance of the results (Figure 1). Two of the most desirable end points for use in the surrogate toxicological bioassay approach are growth and reproduction. If reproductive success is impaired for a sufficient period of time, the viability of a population may be at risk. In addition, somatic growth and reproductive or gametic growth represent competing energy demands on the bioenergetics of aquatic animals. Therefore, if exposure to contaminated sediment is shown to reduce somatic growth, then reproductive success may also be adversely affected.

Both end points, growth and reproduction, are widely accepted in the scientific community as ecologically relevant. The California RWQCB, for example, has identified growth as a highly desirable end point for sublethal effects. The Board utilizes growth bioassays in its regulatory program for effluent applicants. Test results involving growth and reproduction have 


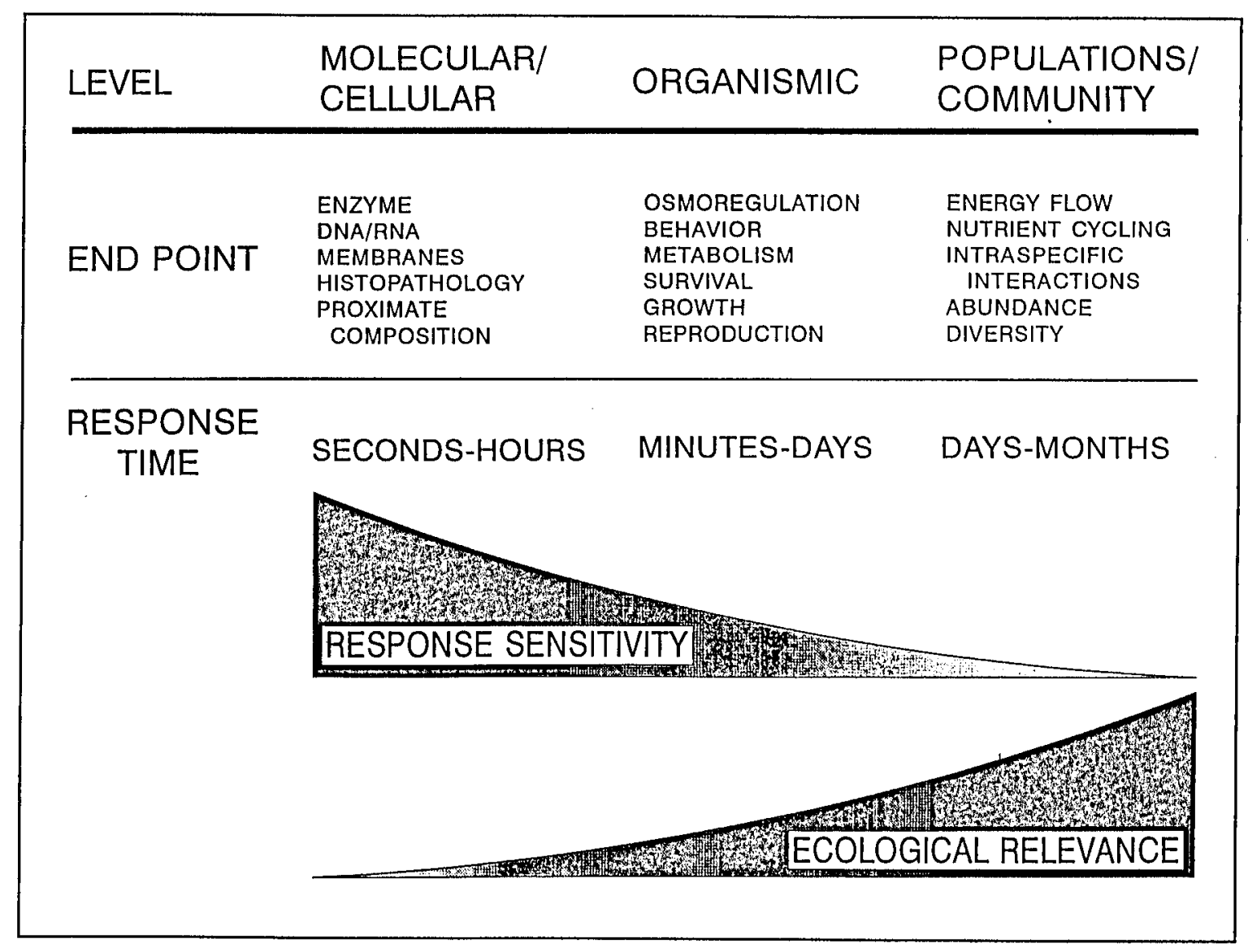

Figure 1. Sublethal end points within levels of biological organization

the additional benefit of being generally understood and appreciated by a wider nontechnical audience. This latter characteristic is a very important consideration since data for large and/or controversial dredging projects will be carefully scrutinized by the public and, perhaps, the courts.

Selection of an appropriate animal model is another important step in developing a chronic sublethal sediment bioassay. The benthic infaunal polychaete worm, Nereis (Neanthes) arenaceodentata will be used to evaluate chronic sublethal effects of San Francisco Bay sediments. Several features make this species particularly well suited for use in sediment toxicity tests. First, it maintains intimate contact with the sediment throughout its entire life cycle. Second, unlike many test organisms, $N$. arenaceodentata can be used to evaluate both solid phase and suspended phase material, allowing direct comparisons to be made between the two phases. Third, $N$. arenaceodentata is a sediment ingester. In both solid phase and suspended phase exposures, it readily ingests sediments while foraging for food and tube-building material. Fourth, it is well suited for monitoring of reproductive end points because, unlike most nereid polychaetes, it has no planktonic trochophore larvae. Instead, development is via metatrochophore larvae that are easier to observe and manipulate from an experimental standpoint. Finally, because the whole life cycle can be completed 
in the laboratory, cultures producing test organisms of known age and background are possible. This is an attractive logistical characteristic from the perspective of regulatory testing.

Test protocols for a chronic sublethal sediment bioassay with $N$. arenaceodentata have already been developed for the Corps' Seattle District in cooperation with the State of Washington and Region X of the USEPA. A guide entitled "Guide for Conducting Acute and Chronic Sediment Toxicity Test with Polychaetous Annelids" is also currently under consideration by ASTM. Both of these tests are 20-day juvenile growth assays initiated with 3-week-old $N$. arenaceodentata. In addition, important nontreatment effects on survival and growth in the growth assay with juvenile $N$. arenaceodentata have been addressed in Moore and Dillon (in preparation).

To have regulatory utility, any chronic sublethal sediment bioassay must be accompanied by technically sound interpretive guidance. For $N$. arenaceodentata, this guidance must be able to answer the following question: "What diminution in growth is biologically important to $N$. arenaceodentata?" For example, if growth in Sediment A is statistically different from Sediment B by 15 percent, is that difference biologically important? What is the minimum required level of absolute growth (milligrams dry weight) or growth rate (milligrams dry weight day $^{-1}$ ) for $N$. arenaceodentata? To provide answers to questions such as these, one must first establish the relationship between growth and reproductive success.

This report will focus on the relationship between growth and subsequent reproductive success in the marine polychaete $N$. arenaceodentata. The report will conclude with a series of recommendations for evaluating results of chronic sublethal bioassays with the marine polychaete Neanthes. Future reports will focus on interpretative guidance for reproductive end points, bioaccumulation and chronic sublethal effects of sediments from selected sites in the San Francisco Bay area, direct effects of Bay area sediments on fecundity and larval development, effects of food ration on test end points, effect of storage on sediment toxicity, and a discussion of quality assurance/quality control procedures for chronic sublethal sediment bioassays. 


\section{Material and Methods}

\section{Test Species}

Nereis (Neanthes) arenaceodentata is a benthic infaunal polychaete widely distributed in shallow marine and estuarine benthic habitats of Europe, all three coasts of North America, and the Pacific (Reish 1957, 1963; Sanders et al. 1962; Pettibone 1963; Reish and Alosi 1968; Day 1973; Gardiner 1975; Whitlatch 1977; Taylor 1984). This subsurface deposit-feeder constructs one or more mucoid tubes in the upper 2 to $3 \mathrm{~cm}$ of sediment and ingests sediment particles up to $70 \mu \mathrm{m}$ with a preference for particles around $12 \mu \mathrm{m}$ (Whitlatch 1980). N. arenaceodentata has been accepted by the regulatory community as an appropriate test species for evaluating sediment (USEPA/USACE 1977, 1991; Johns, Gutjahr-Gobell, and Schauer 1985). A considerable amount of toxicological information on a wide variety of environmental contaminants already exists for this species (Reish 1985; Jenkins and Mason 1988; Anderson et al. 1990).

Taxonomists are still debating the appropriate nomenclature for this species. Pettibone (1963), who suggested the name Nereis (Neanthes) arenaceodentata, lists five names in the synonomy for this species: Spio caudatus, Nereis (Neanthes) caudata, Nereis arenaceodentata, Neanthes cricognatha, and Neanthes caudata. Day (1973) dismissed arenaceodentata in favor of acuminata, which was subsequently used by Gardiner (1975), Taylor (1984), and Weinberg et al. (1990). Neanthes arenaceodentata is most commonly used in the toxicological literature. Recent evidence suggests that Atlantic and Pacific populations are genetically dissimilar, reproductively isolated, and are probably of different species (Weinberg et al. 1990). Until the taxonomic status of this species is resolved, the name most familiar to toxicologists will be used and the original source of worms will be reported.

The life cycle of $N$. arenaceodentata is well documented, as are culture methods (Reish 1980). As worms approach sexual maturity, males and females establish pairs and occupy a common tube. Eggs are deposited by the female within the tube, and the male presumably fertilizes the eggs at this time. The spent female either exits the tube and dies within 1 to 2 days or is eaten by the male. The male remains in the tube to incubate and guard the 
developing eggs. He creates a current of water via rhythmic undulations to remove metabolic wastes and prevent hypoxic conditions.

Larval development is direct via nonplanktonic metatrochophore larvae and occurs entirely within the parental tube. Emergent juveniles (EJs) exit the parental tube about 3 weeks after egg deposition. They begin to feed and establish tubes of their own. Juvenile worms grow, and eggs become visible in the coelom of females about 6 weeks postemergence. Egg deposition follows 3 to 7 weeks later. The entire life cycle can be completed in the laboratory in 12 to 16 weeks at 20 to $22{ }^{\circ} \mathrm{C}$. The nonplanktonic benthic larva and paternal care are unique among the Nereidae. This feature also facilitates laboratory culture and the experimental investigation of sublethal effects on growth and reproduction.

\section{Laboratory Cultures}

Stock populations of Nereis (Neanthes) arenaceodentata were obtained in March 1988 from Dr. D. J. Reish, California State University at Long Beach. Laboratory cultures were maintained using methods adapted from those described by Reish (1980) and Pesch and Schauer (1988). Briefly, the EJs were raised to sexual maturity in $38-\mathrm{L}$ aquaria containing $30 \mathrm{~L}$ of 30 -ppt seawater (Instant Ocean) maintained at a temperature of $20^{\circ} \mathrm{C}$. The photoperiod was $12 \mathrm{hr}$ light. Animals were fed a combination of ground Tetramarin flakes $(2 \mathrm{mg} /$ worm) and alfalfa $(1 \mathrm{mg} /$ worm) twice weekly. This feeding regime is sufficient to maintain adequate water quality in a static-renewal system and has been found to produce survival and reproduction consistent with that reported for other laboratory populations of Neanthes (i.e., survival $>80$ percent; fecundity, ca. 100 to 1,000 eggs/ brood; EJ production, ca. 50 to 500 EJs/brood) (Reish 1980; Pesch et al. 1987; Anderson et al. 1990).

Seawater was renewed ( 80 percent of volume) every 3 weeks. This renewal schedule, based on water-quality monitoring data, is sufficient to maintain good water quality. After 10 weeks, worms are paired using the fighting response (Reish and Alosi 1968) and the presence or absence of eggs in the coelom. Unpaired worms were discarded. Pairs were placed in $600-\mathrm{ml}$ beakers with $500 \mathrm{ml}$ of seawater. Gentle aeration was provided via Pasteur pipettes, and the beakers were covered with watch glasses to reduce evaporation. Water was carefully renewed weekly in a manner to avoid disturbing worm pairs.

Beakers were monitored daily for the presence of eggs and EJs. When discovered, EJs were mixed with other broods and returned to the 37-L aquaria to complete the culture cycle. Culture conditions and feeding rations were used in all experiments described below unless otherwise noted. 


\section{Juvenile Growth}

Growth of juvenile worms was determined weekly from the time of initial emergence from the parental tube to 12 weeks postemergence. EJs were taken from culture and randomly assigned to 4-L, all-glass aquaria containing $3 \mathrm{~L}$ of seawater. There were three aquaria per sampling period and 12 worms per aquarium. Pesch et al. (1987) reported this stocking density (i.e., $>21 \mathrm{~cm}^{2} /$ worm) had no adverse effect on survival, growth, and reproduction in $N$. arenaceodentata. Water quality monitoring indicated complete seawater renewal every 3 weeks was sufficient to avoid the buildup of ammonia. At weekly intervals, all worms were removed from three aquaria and counted. Individual worms were briefly rinsed in reverse osmosis filtered water, placed on small, tared aluminum pans, and dried at $60{ }^{\circ} \mathrm{C}$ to a constant weight (ca. $24 \mathrm{hr}$ ). They were brought to room temperature under desiccation and weighed to the nearest $0.01 \mathrm{mg}$.

\section{Growth-Reproduction Relationship}

A gradient in worm growth was created by manipulating normal food ration. There were five treatments of geometrically decreasing food rations $(1.00 \mathrm{X}, 0.50 \mathrm{X}, 0.25 \mathrm{X}, 0.12 \mathrm{X}$, and $0.06 \mathrm{X})$ where $\mathrm{X}=$ the normal food ration used in laboratory culture. The test was initiated by randomly distributing juvenile worms ( 2 to 10 days old) from culture to $38-\mathrm{L}$ aquaria (50 worms/aquarium). This stocking density permits adequate growth and development in $N$. arenaceodentata cultured in the absence of sediment (Pesch et al. 1987). There were six aquaria/treatment. All test conditions were the same as worm cultures unless noted otherwise. Food slurries were prepared and administered twice weekly (Tuesdays and Fridays) for each treatment. Premeasured portions of Tetramarin and alfalfa were added to $60 \mathrm{ml}$ of seawater and stirred for 3 to $4 \mathrm{hr}$. Each aquaria received $10 \mathrm{ml}$ of this food slurry. Dissolved oxygen, salinity, temperature, and $\mathrm{pH}$ were monitored weekly. In addition, $30-\mathrm{ml}$ samples were collected from each aquaria prior to renewal, fixed with $50 \mu \mathrm{l} 1 \mathrm{M} \mathrm{HCl}$, refrigerated, and subsequently analyzed for total ammonia using an Orion ion-selective electrode.

Every 3 weeks $(3,6,9$ weeks) five worms from each aquarium (30 per treatment) were removed, briefly rinsed in seawater, placed on tared aluminum pans (one worm/pan), and individually weighed to the nearest 0.01 $\mathrm{mg}$ on an electrobalance. Worms were returned to their respective aquaria immediately (i.e., worms were out of water no longer than $1 \mathrm{~min}$ ) following wet weight determinations. After 9 weeks, all worms were removed from each aquarium and counted. Forty pairs of worms were established from each treatment (survival permitting) to evaluate reproductive success. Beakers containing mated pairs were randomly assigned to either of two types of observations: (a) egg deposition (20 pairs/treatment) or (b) EJ production (20 pairs/treatment). All beakers were observed daily. 
When an egg mass was discovered in beakers assigned to egg deposition, it was carefully removed and total number of eggs determined. Beakers assigned to EJ production were terminated when EJs first appeared outside the parental tube. EJs were carefully removed using a No. 3 camel hair brush and counted. All EJs from a single brood were placed on a preweighed aluminum pan and dried for $24 \mathrm{hr}$ at $60^{\circ} \mathrm{C}$. Estimated individual EJ dry weight was obtained by dividing the total dry biomass by the total number of EJs within a brood. A summary of experimental activities is shown in Figure 2.

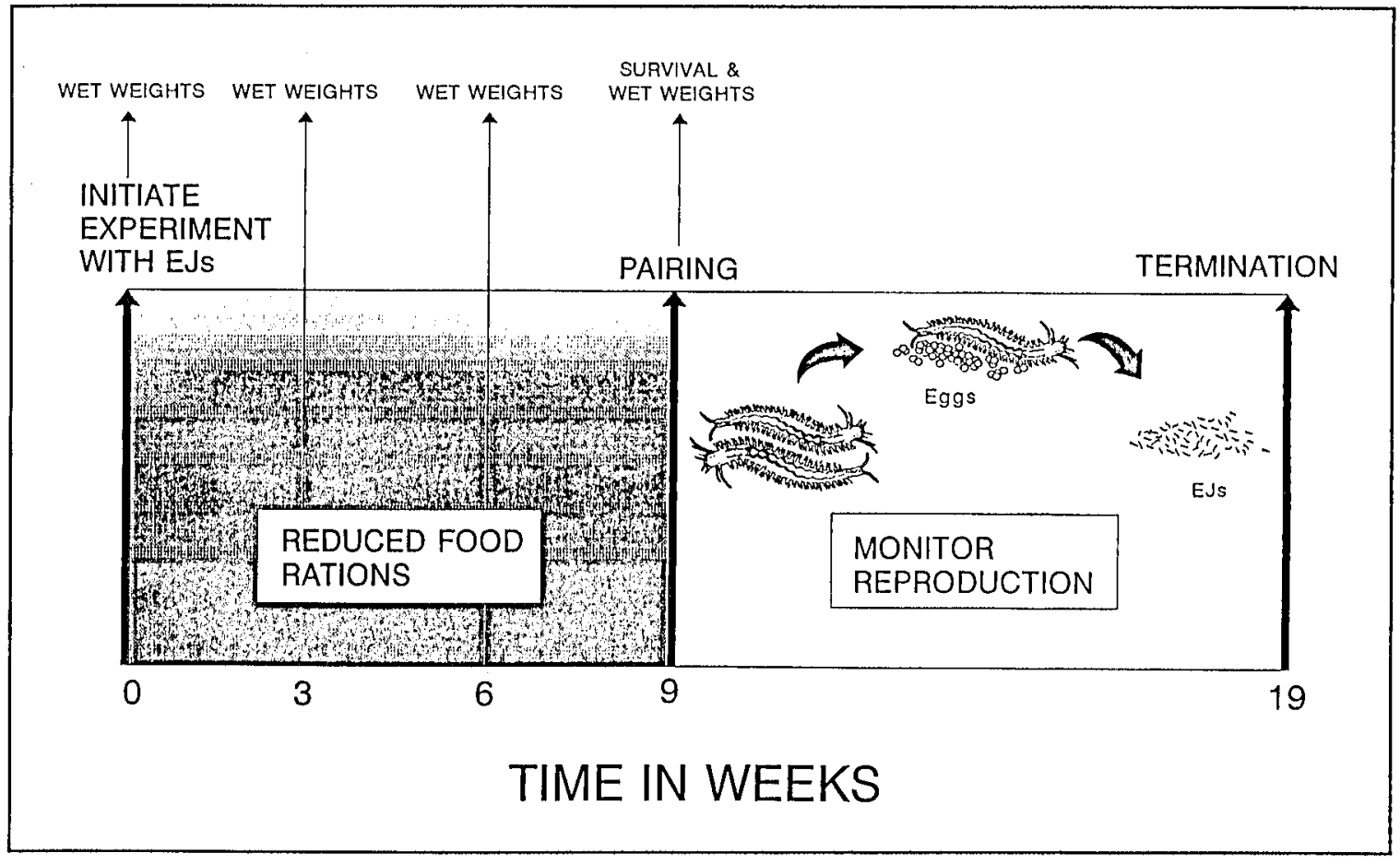

Figure 2. Experimental timetable for exposure of $N$. arenaceodentata to a food ration gradient

\section{Data Analysis}

Statistical analysis and data transformation was conducted using SYSTAT statistical software (Wilkinson 1988). Homogeneity of variance was evaluated for each biological end point using Bartlett's test for Homogeneity of Variance. If this analysis showed unequal variances for a particular end point, various transformations were applied and the transformed data set was then reevaluated for homogeneity. Consequently, wet weights at 3 and 6 weeks were $\log$ transformed while wet weights at 9 weeks were transformed to their square roots to equalize the variances prior to analysis. Treatment effects were analyzed using analysis of variance with subsequent mean separation via Tukey's HSD (Honestly Significant Difference) test. All tests for significance were analyzed at a significance level of $\alpha=0.05$. 
To facilitate graphical presentation, only statistical differences relative to the reference treatment (i.e., 1.00X) are shown in Figures 2, 3, and 4-6.

Growth over three time intervals ( 0 to 3,3 to 6 , and 6 to 9 weeks) was expressed as a rate using the following equation:

$$
G=\frac{W T_{t_{2}}-W T_{t_{1}}}{t_{2}-t_{1}}
$$

where

$$
\begin{aligned}
G & =\text { growth rate, } \mathrm{mg} / \text { day } \\
\mathrm{WT}_{\mathrm{t}_{2}} & =\text { mean wet weight of worms at time } \mathrm{t}_{2} \\
\mathrm{WT}_{\mathrm{t}_{1}} & =\text { mean wet weight of worms at time } \mathrm{t}_{1} \\
\mathrm{t}_{2}-\mathrm{t}_{1} & =\text { length of the time interval }
\end{aligned}
$$

Mean wet weight of EJs from our laboratory culture (mean $=0.03 \mathrm{mg}, \mathrm{SE}$ $=0.001, \mathrm{n}=50$ ) was used to calculate growth rates for the 0 - to 3 -week time interval. 


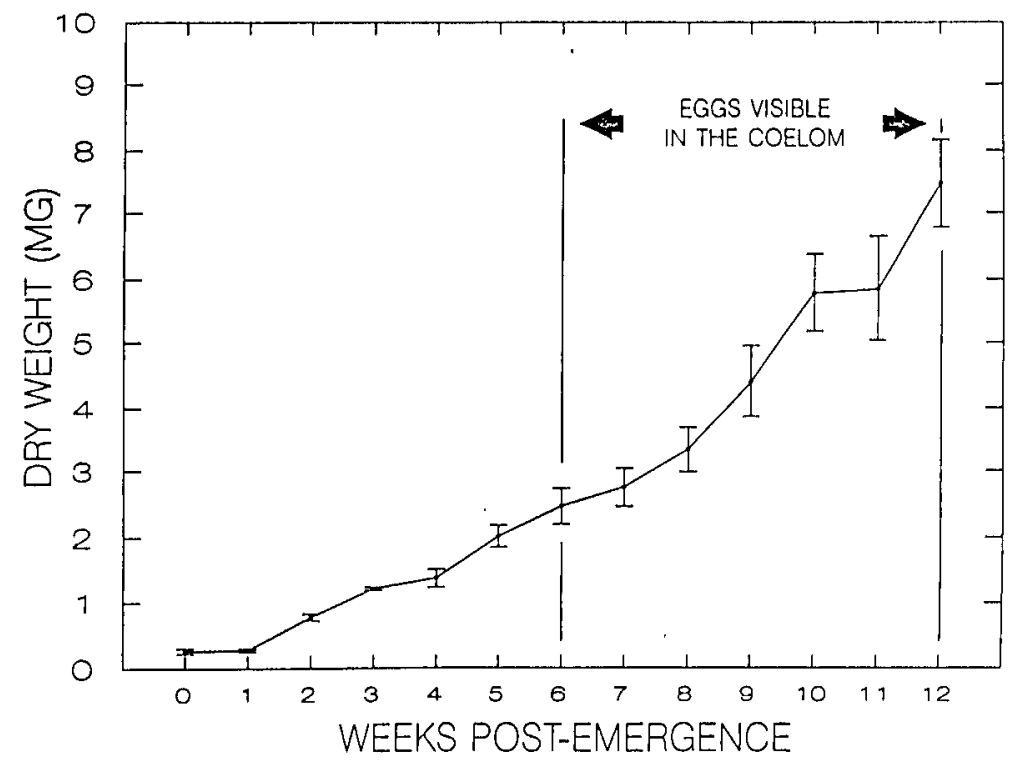

Figure 3. Mean individual dry weights (in milligrams) of $N$. arenaceodentata measured at weekly intervals over a 12-week period. Error bars = standard error of the mean

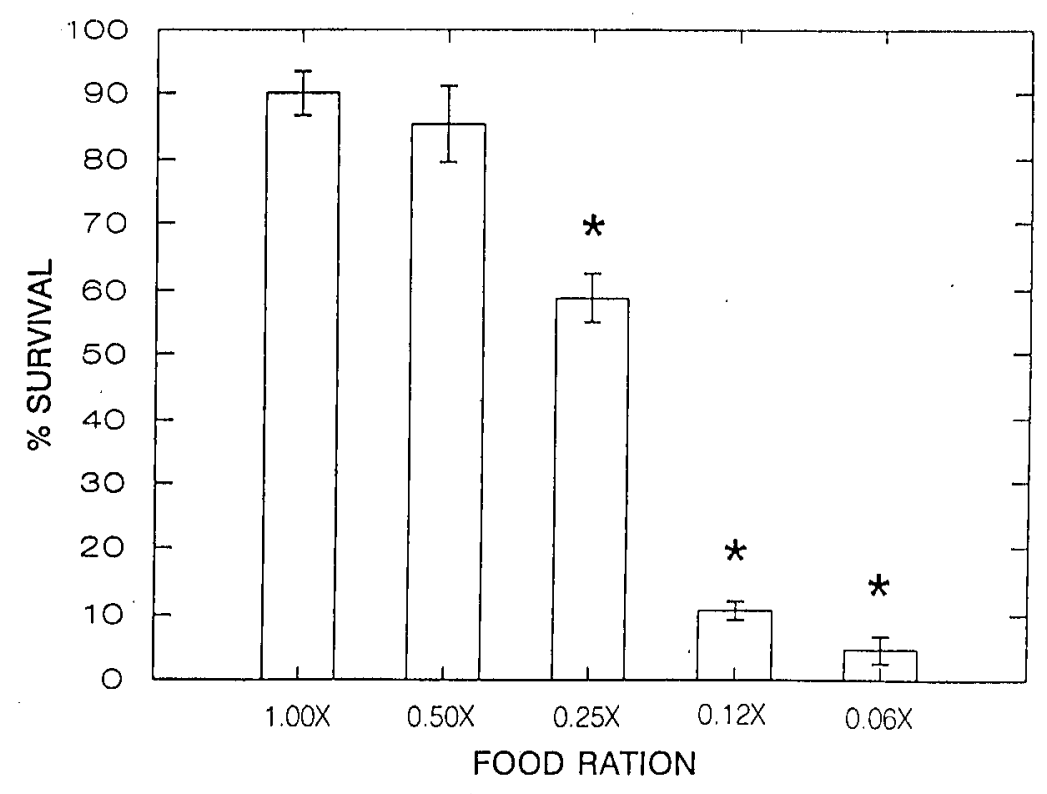

Figure 4. Percent survival of $N$. arenaceodentata after 9 weeks on reduced food rations. Normal food ration $=1.00 \times$ (see text for details). Vertical error bars $=\mathrm{SE}$. Asterisks $=$ significantly different from $1.00 \times$ treatment $(P<0.05) . \quad N=300$ 


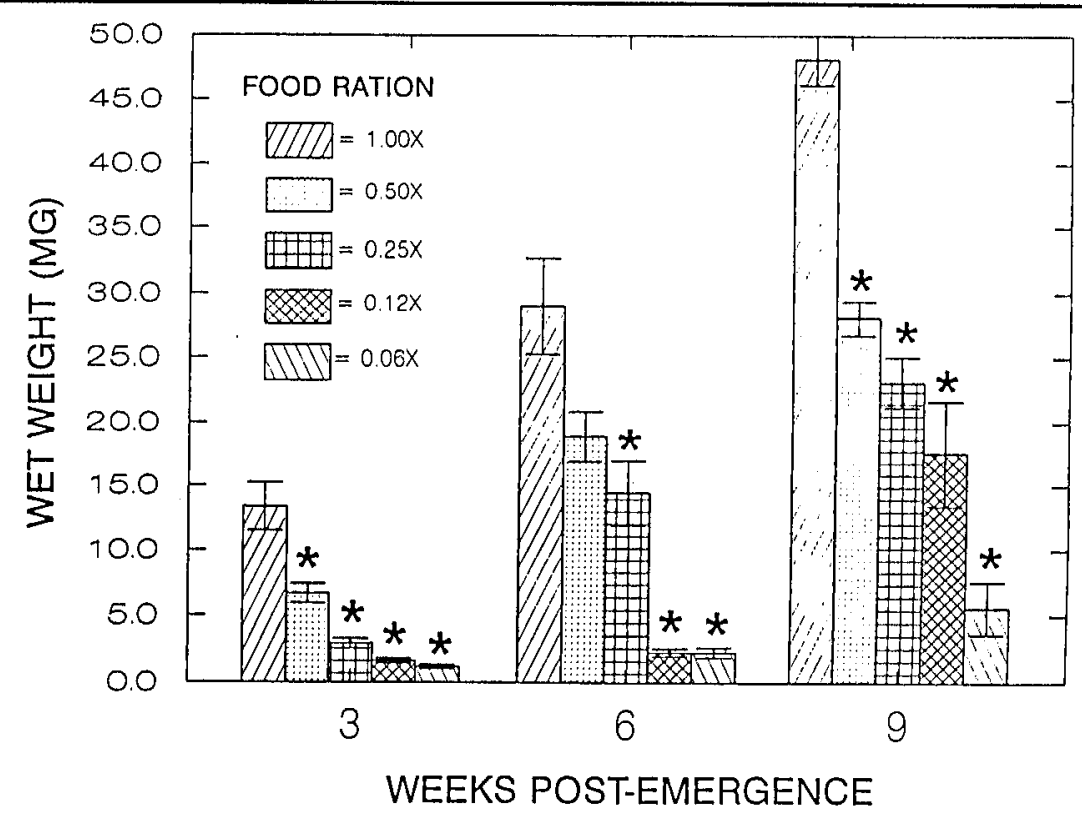

Figure 5. Mean individual wet weights (in milligrams) of $N$. arenaceodentata after 3,6 , and 9 weeks on reduced food rations. Vertical error bars = standard error. Asterisks $=$ significantly different from 1.00X treatment $(P<0.05) . N=30$

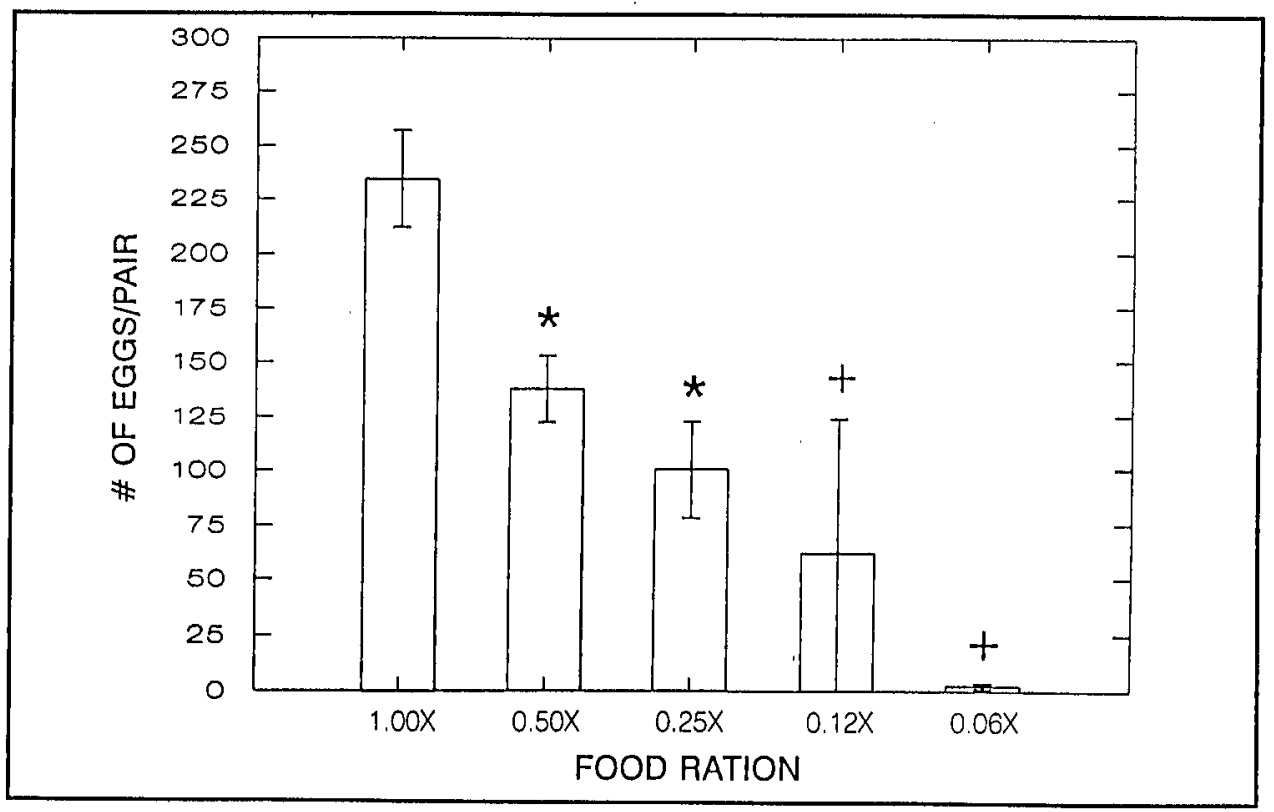

Figure 6. Fecundity (mean number of eggs/all replicates) in $N$. arenaceodentata after 9 weeks on reduced food rations. Vertical error bars $=\mathrm{SE}$. Asterisks = significantly different from $1.00 \mathrm{X}$ treatment $(P<0.05)$. Plus sign $=$ treatment excluded from statistical analysis because of low number of replicates. $N=40$ for the three highest treatments $(1.00 \mathrm{X}, 0.50 \mathrm{X}, 0.25 \mathrm{X})$ and $N=6$ for the lowest two treatments $(0.12 X$ and $0.06 X)$ 


\section{Results}

\section{Juvenile Growth}

The growth of juvenile $N$. arenaceodentata measured as dry weight over a 12-week period is curve linear (Figure 3 ). This growth curve can be visually broken into three sections. During the initial portion of the curve (i.e., the first week of emergence), there is no change in growth. From 1- to 8-weeks postemergence growth appears to be relatively linear. Regressing only the 1- to 8-week data yields the following linear equation.

$$
\mathrm{Y}=-0.150+0.062 \mathrm{X} \quad \quad\left(\mathrm{r}^{2}=0.95\right)
$$

After 8 weeks postemergence, dry weights become more variable and growth appears to be more closely approximated by a quadratic rather than a linear equation. At about 6 weeks, postemergence eggs first appear in the ceolom of female worms (Figure 3).

\section{Growth-Reproduction Relationship}

\section{Survival and Growth}

Survival after 9 weeks in the three lowest treatments $(0.06 \mathrm{X}, 0.12 \mathrm{X}$, and $0.25 \mathrm{X})$ was significantly lower than the normal $(1.00 \mathrm{X})$ food ration (Figure 4). Mean percent survival was 5,11 , and 59 percent, respectively. Survival in the $1.00 \mathrm{X}$ ( 90 percent) and $0.50 \mathrm{X}$ ( 85 percent) treatments were not significantly different from each other. Results of the statistical analysis for this and other life history traits are found in Table 3.

Diminished growth mirrored the reduced food rations at all three time intervals (Figure 5). After 3 weeks, worm wet weights in all treatments were significantly different from one another. After 6 and 9 weeks, these differences persisted but were not as statistically distinct (Table 3). Eggs were first observed in the coelom of female worms at the 6-week interval. 


\section{Table 3 \\ Effect of Reduced Food Ration (See Text for Food Rations) on Survival, Individual Worm Growth, and Reproduction in N. arenaceodentata}

\begin{tabular}{|c|c|c|c|c|c|}
\hline \multirow{2}{*}{ Life-History Trait } & \multicolumn{5}{|c|}{ Food Ration } \\
\hline & $1.00 \mathrm{X}$ & $0.50 \mathrm{X}$ & $0.25 X$ & $0.12 X$ & $0.06 x$ \\
\hline Survival, \% & $\begin{array}{l}90 \\
(3.3)\end{array}$ & $\begin{array}{l}85 \\
(5.7)\end{array}$ & $\begin{array}{l}59 \\
(3.8)\end{array}$ & $\begin{array}{l}11 \\
(1.4)\end{array}$ & $\begin{array}{l}5 \\
(2.1)\end{array}$ \\
\hline $\begin{array}{l}\text { Growth, mg wet wt. } \\
\text { After } 3 \text { weeks }\end{array}$ & $\begin{array}{l} \\
13.37 \\
(1.82)\end{array}$ & $\begin{array}{c}6.64 \\
(0.72)\end{array}$ & $\begin{array}{c}2.93 \\
(0.36)\end{array}$ & $\begin{array}{c}1.65 \\
(0.20)\end{array}$ & $\begin{array}{l}1.20 \\
(0.16)\end{array}$ \\
\hline After 6 weeks & $\begin{array}{l}28.96 \\
(3.66)\end{array}$ & $\begin{array}{l}18.90 \\
(1.96)\end{array}$ & $\begin{array}{l}14.46 \\
(2.46)\end{array}$ & $\begin{array}{c}2.29 \\
(0.27)\end{array}$ & $\begin{array}{c}2.28 \\
(0.53)\end{array}$ \\
\hline After 9 weeks & $\begin{array}{l}48.18 \\
(2.06)\end{array}$ & $\begin{array}{l}28.04 \\
(1.35)\end{array}$ & $\begin{array}{l}23.18 \\
(1.91)\end{array}$ & $\begin{array}{l}17.59 \\
(4.16)\end{array}$ & $\begin{array}{c}5.59 \\
(1.95)\end{array}$ \\
\hline $\begin{array}{l}\text { Reproduction } \\
\text { Worms with eggs, }{ }^{1} \%\end{array}$ & 34 & 33 & 12 & 3 & 7 \\
\hline Reproductive success, ${ }^{2} \%$ & 95 & 65 & 58 & 17 & 17 \\
\hline $\begin{array}{l}\text { Egg production } \\
\text { All replicates }\end{array}$ & $\begin{array}{l}\overline{234} \\
(23)\end{array}$ & $\begin{array}{l}138 \\
(18)\end{array}$ & $\begin{array}{l}101 \\
(22)\end{array}$ & $\begin{array}{c}62 \\
(62)\end{array}$ & $\begin{array}{c}2 \\
(4)\end{array}$ \\
\hline Reproducing pairs only & $\begin{array}{l}\overline{260} \\
(17)\end{array}$ & $\begin{array}{l}172 \\
(11)\end{array}$ & $\begin{array}{l}155 \\
(22)\end{array}$ & $\begin{array}{r}186^{3} \\
(0)\end{array}$ & $\begin{array}{l}7^{3} \\
(0)\end{array}$ \\
\hline $\begin{array}{l}\text { EJ production } \\
\text { All replicates }\end{array}$ & $\begin{array}{l}\overline{145} \\
(21)\end{array}$ & $\begin{array}{c}52 \\
(16)\end{array}$ & $\begin{array}{c}23 \\
(14)\end{array}$ & $\begin{array}{c}0 \\
(0)\end{array}$ & $\begin{array}{c}0 \\
(0)\end{array}$ \\
\hline Reproducing pairs only & $\begin{array}{l}145 \\
(21)\end{array}$ & $\begin{array}{c}94 \\
(20)\end{array}$ & $\begin{array}{c}62 \\
(26)\end{array}$ & $\begin{array}{c}0 \\
(0)\end{array}$ & $\begin{array}{c}0 \\
(0)\end{array}$ \\
\hline EJ size $e^{4}$ & $\begin{array}{l}22 \\
(4.0)\end{array}$ & $\begin{array}{l}19 \\
(2.0)\end{array}$ & $\begin{array}{l}20 \\
(2.0)\end{array}$ & NA & NA \\
\hline Hatching success, ${ }^{5} \%$ & 56 & 55 & 40 & 0 & 0 \\
\hline $\begin{array}{l}\text { Note: Means (SE) under the sa } \\
\text { NA = not applicable. Note in the } \\
\text { reproductive end points. } \\
1 \text { (\# worms with eggs visible in c } \\
2 \text { (\# pairs successfully depositing } \\
3 \text { Single observation. } \\
4 \text { Estimate for each brood from } \\
5 \text { Estimate from (mean EJs/repr }\end{array}$ & $\begin{array}{l}\text { line are no } \\
2 X \text { and } 0.0 \\
\text { m) }{ }^{\star}(\# \text { wor } \\
\text { eggs insid } \\
\text { EJ biomas } \\
\text { ing pair) }{ }^{\star}(\end{array}$ & $\begin{array}{l}\text { atments, } p \\
\text { ueek } 9)^{-1} \text {. } \\
\text { ube })^{*}(\# \text { pa } \\
\text { drý) }{ }^{\star}(\# \text { EJs } \\
\text { eggs/repro }\end{array}$ & $\begin{array}{l}\text { vival precl } \\
\text { pair) }{ }^{-1} \text {. }\end{array}$ & $\begin{array}{l}\text { mergent } \\
\text { tatistical }\end{array}$ & $\begin{array}{l}\text { worms, } \\
\text { of }\end{array}$ \\
\hline
\end{tabular}


After observations of growth were made at the 9-week interval, worms were paired to observe reproductive success. Forty pairs of worms were created in the three highest food treatments: $1.0 \mathrm{X}, 0.5 \mathrm{X}$, and $0.25 \mathrm{X}$. However, pair formation in the two lowest treatments $(0.12 \mathrm{X}$ and $0.06 \mathrm{X})$ was problematic. Not only was survival low (5 to 11 percent), but very few worms could be sexed; $\leq 7$ percent had eggs visible in the coelom, and the fighting reaction was practically nonexistent. Only six pairs could be established in each of these two treatments. As will be seen below, reproductive activities in these few pairs of worm was practically nonexistent. None produced any juvenile worms. For this reason and because of the very unequal replicate number, vis a vis the other treatments, the $0.06 \mathrm{X}$ and $0.12 \mathrm{X}$ treatments were excluded from subsequent statistical analyses.

\section{Reproduction}

Like growth, almost every measure of reproduction was reduced in a manner that mirrored the decreasing food rations. For example, the number of worms with eggs visible in the coelom at time of pairing decreased from a high of 34 percent in the $1.0 \mathrm{X}$ treatment to 3 to 7 percent (Table 1). Reproductive success, that is the proportion of pairs in each treatment successfully depositing all eggs inside the tube, was $95,65,58,17$, and 17 percent in the $1.0 \mathrm{X}, 0.5 \mathrm{X}, 0.25 \mathrm{X}, 0.12 \mathrm{X}$, and $0.06 \mathrm{X}$ treatments, respectively (Table 3 ).

There was also a significant gradient in fecundity, which mirrored food ration (Figure 6). Mean egg production was significantly lower in the $0.50 \mathrm{X}$ and $0.25 \mathrm{X}$ treatments (138 and $101 \mathrm{eggs} / \mathrm{pair}$, respectively) compared with the $1.00 \mathrm{X}$ treatment (234 eggs/pair). A similar gradient was observed when only reproducing pairs were considered (Table 3 ). Only one pair out of six in each of the two lowest treatments deposited eggs.

EJ production also diminished significantly at lower food ration (Figure 7). Worm pairs in the $1.00 \mathrm{X}$ treatment produced nearly 3 to 6 times more EJs than either the $0.50 \mathrm{X}$ or $0.25 \mathrm{X}$ treatments. A similar but nonsignificant pattern was observed when only the reproductively successful pairs were considered (Table 3). Pairs in the two lowest treatments failed to produce any EJs. The estimated individual dry weight of EJs produced was essentially the same in all treatments $(20 \mathrm{~g})$ (Table 3$)$.

The experimental observations do not allow one to directly determine the proportion of eggs in each brood that successfully developed into EJs. However, this end point can be estimated indirectly by dividing the mean number of EJs produced per reproducing pair in each treatment by the mean fecundity in that treatment. This calculation yields an estimate of percent hatch. As seen in Table 3, hatching success is slightly lower ( 40 percent) in the $0.25 \mathrm{X}$ treatment than in the two highest food rations (1.00X and $0.50 \mathrm{X})$ where hatch estimates were 56 and 55 percent, respectively. 


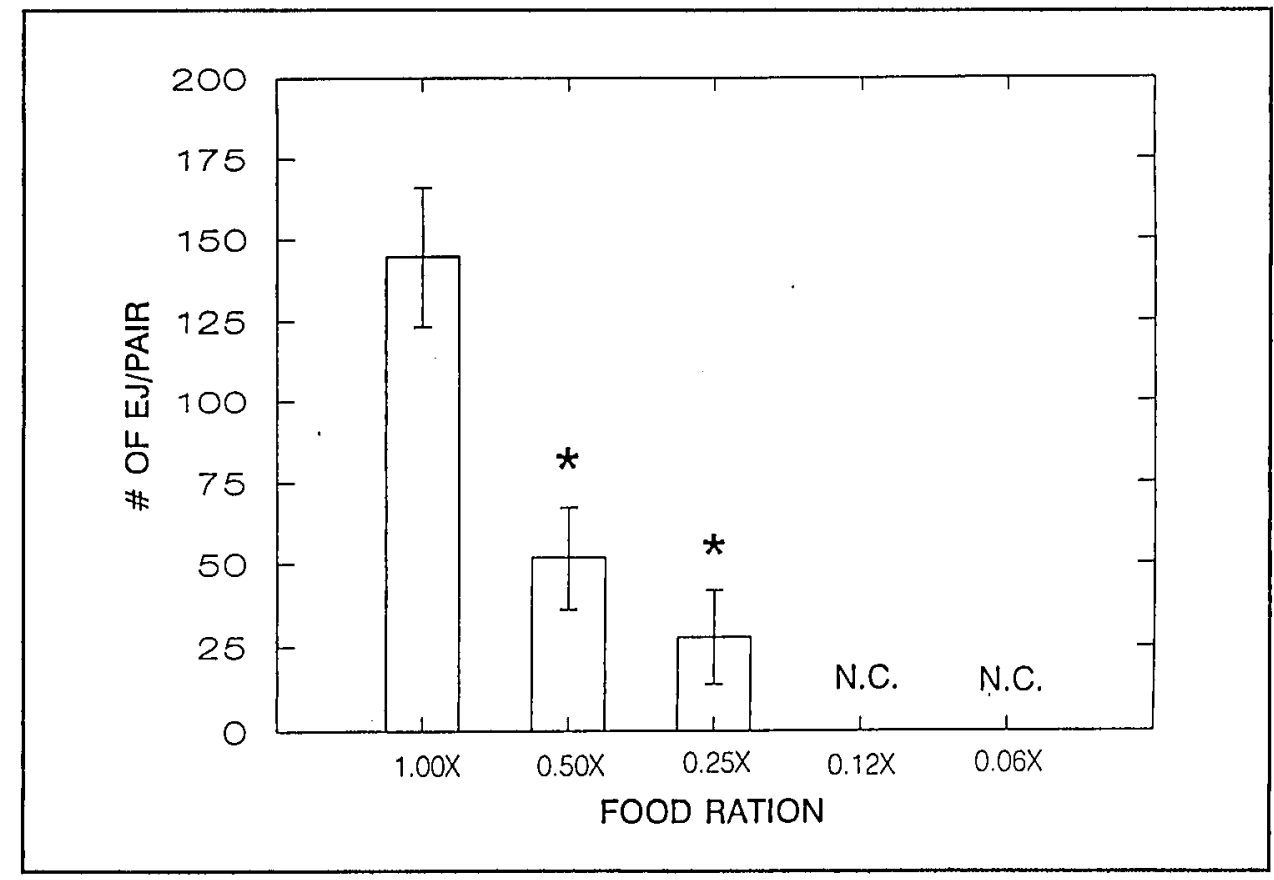

Figure 7. EJ production (mean number of EJs/all replicates) in $N$. arenaceodentata after 9 weeks on reduced food rations. Vertical error bars $=$ standard error of the mean. Asterisks $=$ significantly different from 1.00X treatment $(P<0.05) . N=40$ for the three highest treatments $(1.00 \mathrm{X}, 0.50 \mathrm{X}, 0.25 \mathrm{X})$ and $\mathrm{N}=6$ for the two lowest treatments $(0.12 X$ and $0.06 X)$. N.C. $=$ Means could not be calculated for the $0.12 \mathrm{X}$ or $0.06 \mathrm{X}$ treatments since there was no EJ production.

In the three highest treatments (1.00X, 0.50X, and $0.25 \mathrm{X})$, timing of reproductive events was not significantly affected by reduced food ration. Approximately 25 days elapsed between pairing and egg deposition. Another 25 days passed between egg deposition and the appearance of EJs (Figure 8). 


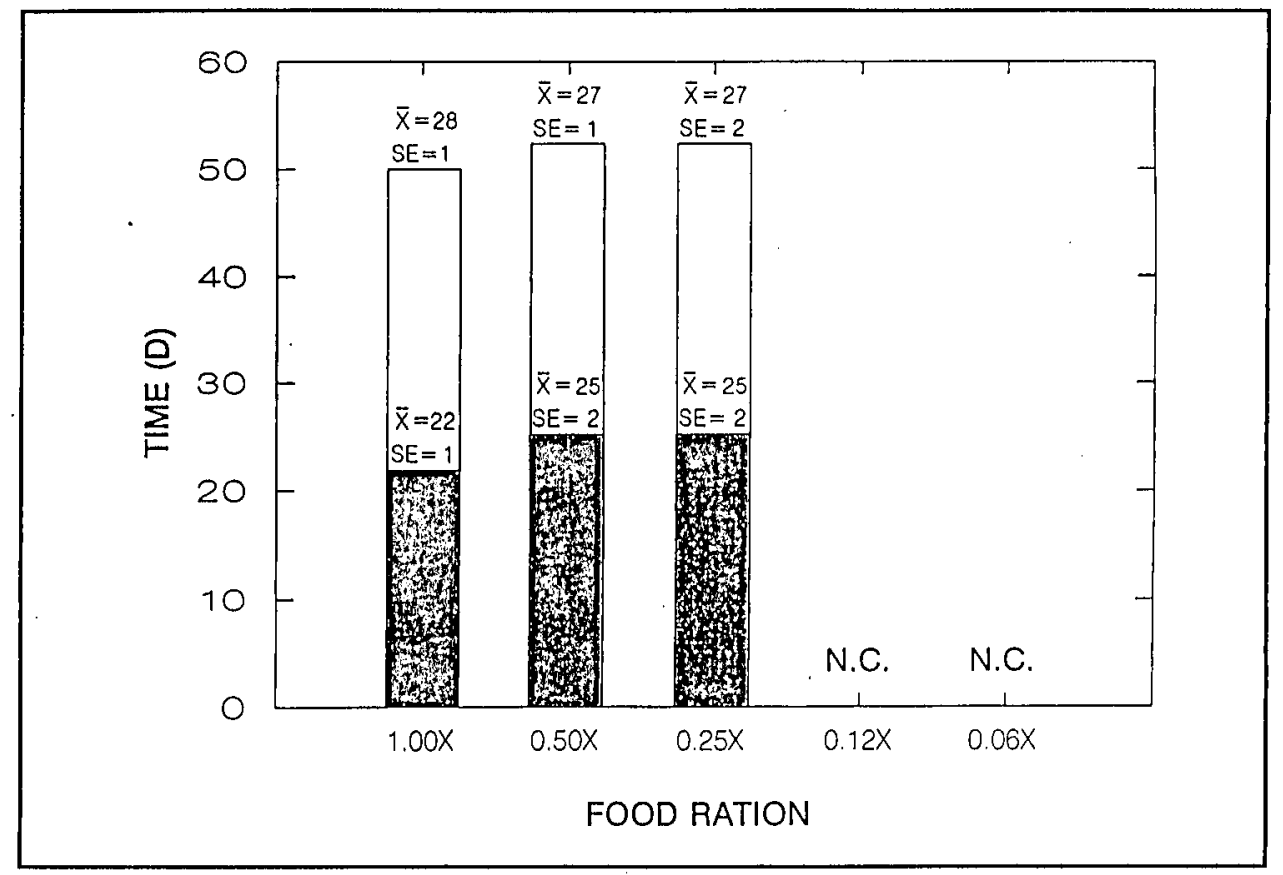

Figure 8. Mean time (days) between reproductive events in $N$. arenaceodentata after a 9-week exposure to reduced food rations. Filled portion of bar represents time from pairing to egg deposition. Open portion represents time from egg deposition to juvenile emergence. Total bar height represents time from pairing to juvenile emergence. $N$.C. = means could not be calculated for the $0.12 \mathrm{X}$ or $0.06 \mathrm{X}$ treatments (only a single replicate reproduced) 


\section{Discussion}

The toxicity of sediments has typically been measured in terms of survival of sensitive species following acute ( 4 to 10 days) exposures. However, benthic infaunal organisms generally experience prolonged exposure to low levels of environmentally persistent contaminates. Consequently, a second generation of sediment toxicity tests are being developed to evaluate the potential chronic sublethal effects of contaminated sediments (Dillon, Moore, and Gibson, in preparation). Two highly desirable test end points in these second generation bioassays are growth and reproduction. Growth integrates the many biochemical and behavioral processes that could be adversely affected by contaminant exposure. Once growth has been impacted, energy reserves available for subsequent reproduction may no longer be available. In this way, growth and reproduction are inextricably linked. This report provides initial interpretative guidance for a chronic sublethal sediment bioassay in which growth is measured in the marine polychaete worm Neanthes (Nereis) arenaceodentata following 28-day sediment exposure.

In providing this interpretive guidance for the growth end point, it is important to distinguish between somatic growth and gametic growth. In most nereid polychaetes, somatic cell growth, i.e., number and size of individual cells, increases during the early life stages (Clark 1965). Gamete cell growth occurs later as worms approach sexual maturity. The regulatory mechanisms governing somatic and gametic growth are mediated via a complex neuroendocrine system. Baskin (1976) demonstrated that normal segment proliferation and regenerative growth in young nereid polychaetes (somatic growth) is promoted by high concentrations of a hormone secreted by the brain. High concentrations of this same hormone inhibits spermatogenesis and oogenesis (gametic growth) (Baskin 1976; Dhainaut 1984). As worms mature, titers of this hormone decrease and gametogenesis proceeds. Mature worms are generally incapable of somatic growth (e.g., segment regeneration) unless elevated brain hormone titers are restored experimentally. Once nereid eggs begin developing in the coelom, secretion of a separate tropic hormone initiates vitellogenesis (Baskin 1976). In $N$. arenaceodentata, egg yolk production is dependent on circulating coelomocytes called eleocytes (Davis and Reish 1975). Eleocytes extract lipids and carbohydrates from the worm's internal musculature and transfer them to developing oocytes. In effect, the energy and metabolic 
substrates acquired during somatic growth are enjoined to support gametogenesis. In one sense, somatic and gametic growth are energetic antagonists since they compete for the same pool of limited metabolic resources. Somatic and gametic growth are distinct processes under disparate regulatory control. Environmental contaminants would likely affect each type of growth in a different manner. Thus, somatic and gametic growth should be distinguished in chronic sediment bioassays.

The gametic contribution to total body mass probably becomes quantitatively important in $N$. arenaceodentata sometime after 6-weeks postemergence. At this point eggs first become visible in the coelom. A deviation from linear growth occurs in $N$. arenaceodentata older than 6-weeks postemergence. This deviation from linearity is speculated to be due to advancing oogenesis in female worms. Eggs were also observed in the coeloms of female worms beginning at about 6-weeks postemergence. Similarly, Reish (1957) has also reported first observing eggs in the coelom of female $N$. caudata ( $N$. arenaceodentata) between 40 and 50 days postemergence (about 6 weeks). For this reason, measures of somatic growth in sediment bioassays with $N$. arenaceodentata should not be made in worms older than 6 weeks.

Results of this study indicate that reduced growth in $N$. arenaceodentata is associated with adverse effects on reproductive success. If the above recommendation to only measure somatic growth in juvenile worms (i.e., those $\leq 6$-weeks postemergence) is accepted, then the growth-reproduction relationship to observations during that same time period must also be restricted. Growth rates (milligrams wet weight/day) of juvenile $N$. arenaceodentata during the first six weeks mirrored the diminished food ration treatments (Table 4). The growth rate of worms in the 1.00X treatment $(0.69 \mathrm{mg} /$ day) was significantly higher than all other treatments. Mean growth rates in the two intermediate treatments, $0.50 \mathrm{X}$ and $0.25 \mathrm{X}$, were not significantly different, $0.45 \mathrm{mg} /$ day and $0.34 \mathrm{mg} /$ day, respectively. In the two lowest treatments $(0.12 \mathrm{X}$ and $0.06 \mathrm{X})$ where survival was very low and reproduction practically nonexistent, mean growth rates were significantly smaller ( $\leq 0.06 \mathrm{mg} / \mathrm{day})$ than all other treatments. The relationship between growth rate and reproduction can be summarized as follows. If growth in juvenile $N$. arenaceodentata is $\geq 0.65 \mathrm{mg} /$ day during the first

\section{Table 4 \\ Effect of Reduced Food Ration on Somatic Growth Rate (Milligrams Wet Weight/Day) in $\mathbf{N}$. arenaceodentata. Means (SE) Under the Same Line Are Not Significantly Different $(P<0.05)$}

\begin{tabular}{|c|c|c|c|c|c|}
\hline \multirow[b]{2}{*}{ Time Interval } & \multicolumn{5}{|c|}{ Food Ration } \\
\hline & $1.00 \mathrm{x}$ & $0.50 \mathrm{X}$ & $0.25 \mathrm{X}$ & $0.12 X$ & $0.06 \mathrm{X}$ \\
\hline $\begin{array}{l}0 \text { to } 6 \text { weeks } \\
\text { postemergence }\end{array}$ & $\begin{array}{l}0.69 \\
(0.12)\end{array}$ & $\begin{array}{l}0.45 \\
(0.04)\end{array}$ & $\begin{array}{l}0.34 \\
(0.11)\end{array}$ & $\begin{array}{l}0.06 \\
10.03\end{array}$ & $\begin{array}{c}0.05 \\
(0.02)\end{array}$ \\
\hline
\end{tabular}


6-weeks postemergence, subsequent reproduction should not be adversely affected. Growth rates $\leq 0.45 \mathrm{mg} / \mathrm{day}$ are associated with diminishing reproductive success. Very low growth rates, $\leq 0.06 \mathrm{mg} / \mathrm{day}$, will result in very severe effects on reproduction as well as survival. The advantages of reporting growth as a rate function in sediment bioassays with juvenile $N$. arenaceodentata is discussed in Dillon, Moore, and Gibson, in preparation.

A number of important considerations must accompany the interpretive guidance for growth provided above. The first of these is the potential for recovery. Many examples of physiological recovery in aquatic organisms exists once the contaminant perturbation has been removed (Widdows, Donkin, and Evans 1987; Tam, Payson, and Roy 1986; Zeitoun 1978). Whether adverse effects on reproduction brought on by reduced growth are also reversible is a question yet to be answered. Oogenesis in polychaetes is under endocrine control (Clark 1965; Dhainaut 1984). Older animals may possibly lose the ability to produce or respond to the hormones controlling oocyte development. In a study with the polychaete $N$. diversicolor, Clark and Scully (1964) found that older worms lost their competency to respond to the neuroendocrine hormones governing regenerative growth. Therefore, if conditions affecting growth persist and sufficiently delay the onset of reproduction, the animal may simply lose the ability to reproduce.

Differences in the mode of action may also confound interpretation of the growth end point. For example, a reduction in growth is generally considered an adverse effect; but what if growth increases in response to contaminant exposure? Enhancement of a physiological process by exposure to low levels of contaminants is known as the Arndt-Schulz effect, "sufficient challenge," or hormesis (Laughlin, $\mathrm{Ng}$, and Guard 1981). This effect is well documented (Stebbing 1981; Sanders, Laughlin, and Costlow 1984; Laughlin, $\mathrm{Ng}$, and Guard 1981; Weis and Weis 1986) and is attributed to short-term overcompensation of homeostatic regulatory control mechanisms to an external challenge. Increased growth has been reported for $N$. arenaceodentata exposed to low concentrations of cadmium (Jenkins and Sanders 1986) and DDT (dichlorodiphenyltrichloroethane). ${ }^{1}$ Word found that although worms exposed to DDT grew larger than unexposed worms, reproduction was significantly reduced. Because the reproductive consequences of the hormetic response are not well documented, interpreting such a response will be difficult.

Growth may also be adversely affected by certain contaminants without affecting subsequent reproduction. For example, the P-450 mixed function oxygenase (MFO) system is an important detoxification pathway known to be involved in steroid metabolism, and it is possible that xenobiotic induction of this system may affect growth by altering the

1 Personal Communication, 1992 (Aug), J. Q. Word, Toxicologist, Battelle/Marine Sciences Laboratory, Sequim, WA. 
levels of steroidal hormones. The relationship between MFO induction, xenobiotic metabolism, and steroid production is complex and has been thoroughly discussed in Lee (1988). Whatever the mechanism, hormonally influenced changes in growth may or may not be related to subsequent reproductive success.

Another important consideration for any sediment bioassay where growth is an end point is the potential for differences in growth because of intrasediment nutritional differences. Sediments serve as a food source with some sediments having a higher organic content and therefore higher nutritional value than other sediments. Organic enrichment of sediments has been shown to be directly related to growth in the polychaetes Capitella sp. and Polydora ligni (Tenore 1983; Tsutsumi et al. 1990; Zajac 1986). Taghon and Greene (1990) showed that as the level of enzymatically available protein in sediments declined, the feeding rate increased in the polychaete Abarenicola pacifica until a maximum feeding rate was achieved at 0.05 to $0.1 \mathrm{mg}$ protein/g dry sediment. Above and below this ration, feeding rates declined. Despite this functional adaptation, growth decreased steadily with decreasing protein concentrations. One way to accommodate intrasediment differences in nutritional quality within a test system is to feed the organism ad libitum with a highly nutritious food source such as Tetramarin. The addition of food, however, may reduce exposure as the animals may feed preferentially on the external food source to the exclusion of the test sediments. Also, ad libitum feeding may adversely affect water quality, even in flowing or renewal exposure systems. 


\section{Conclusions}

Conclusions based on this study are summarized below.

- Growth (measured as milligrams dry weight) in Nereis (Neanthes) arenaceodentata is nearly linear $\left(\mathrm{r}^{2}=0.92\right)$ between 1 and 8 weeks postemergence.

- Growth from 0 to 6 weeks postemergence is predominantly somatic.

- Growth after 6 weeks postemergence is predominantly gametic.

- Under conditions of reduced food ration, a decreasing gradient in somatic growth rate corresponds to a decreasing gradient in reproductive success in Neanthes.

- Under conditions of reduced food ration, growth rates $\geq 0.65 \mathrm{mg} /$ day measured between 0 to 6 weeks resulted in no significant effect on either survival or reproduction.

- Under conditions of reduced food ration, growth rates $\leq 0.45 \mathrm{mg} /$ day resulted in significant reductions in reproduction.

- Under conditions of reduced food ration, low growth rates $(0.05 \mathrm{mg} /$ day $)$ were associated with a nearly complete cessation of reproduction and very poor survival ( 5 to 11 percent). 


\section{Recommendations}

Based on the results of this study, the following recommendations are made:

- To reduce variability in the data and uncertainty in interpretation, only somatic growth (0 to 6 weeks) should be measured in Neanthes.

- For a number of reasons (Dillon, Moore, and Gibson, in preparation), worm growth should be expressed as a rate function rather than absolute wet or dry weights.

- Somatic growth rate is a useful surrogate measure for potential reproductive success in Neanthes. 


\section{References}

Anderson, J., Birge, W., Gentile, J., Lake, J., Rogers, J., Jr., and Swartz, R. (1984). "Biological effects, bioaccumulation, and ecotoxicology of sediment associated chemicals," Fate and effects of sediment-bound chemicals in aquatic systems. Chapter 18, K. L. Dickson, A. W. Maki, and W. A. Brungs, ed., Pergamon Press, New York, 267-296.

Anderson, S. L., Harrison, F. L., Chan, G., and Moore II, D. H. (1990). "Comparison of cellular and whole-animal bioassays for estimation of radiation effects in the polychaete worm (Neanthes arenaceodentata)," Arch. Environ. Contam. Toxicol. 19, 164-174.

Baskin, D. G. (1976). "Neurosecretion and the endocrinology of nereid polychaetes," Amer. Zool. 16, 107-124.

Bowden, R. J. (1977). "Guidelines for the pollutional classification of Great Lakes Harbor sediments," Great Lakes National Program.

Clark, R. B. (1965). "Endocrinology and the reproductive biology of polychaetes," Oceanog. Mar. Biol. Ann. Rev. 3, 211-255.

Clark, R. B., and Scully, U. (1964). "Hormonal control of growth in Nereis diversicolor," Gen. Comp. Endocrin. 4, 82-90.

Davis, W. R., and Reish, D. J. (1975). "The effect of reduced dissolved oxygen concentration on the growth and production of oocytes in the polychaetous annelid Neanthes arenaceodentata," Rev. Intern. Oceanogr. Med. Tomes, 37-38.

Day, J. (1973). "New polychaeta from Beaufort, with a key to all species recorded from North Carolina," Circular 375, NOAA Tech. Report NMFS, National Oceanic and Atmospheric Administration, National Marine Fisheries Service, Washington, DC.

Dhainaut, A. (1984). "Oogenesis in polychaetes. Ultrastructural differentiation and metabolism of nereid oocytes," Fortschr. Zool. 29, 183-205. 
Dickson, K. L., Maki, A. W., and Brungs, W. A. (1984). Fate and effects of sediment-bound chemicals in aquatic systems. Pergamon Press, New York.

Dillon, T. M., Moore, D. W., and Gibson, A. B. "Initial development of a chronic sublethal sediment bioassay with the marine polychaete worm, Nereis (Neanthes) arenaceodentata," In preparation, Environmental Toxicology and Chemistry.

Gannon, J. E., and Beeton, A. M. (1971). "Procedures for determining the effects of dredged sediments on biota-benthos viability and sediment selectivity tests," J. Water Pollut. Control Fed. 43, 392-398.

Gardiner, S. L. (1975). "Errant polychaete annelids from North Carolina," J. Elisha Mitchell Sci. Soc. 91, 149-150.

Jenkins, K. D., and Mason, A. Z. (1988). "Relationships between subcellular distributions of cadmium and perturbations in reproduction in the polychaete Neanthes arenaceodentata," Aquatic Toxicol. 12, 229-244.

Jenkins, K. D., and Sanders, B. H. (1986). "Relationships between free cadmium ion activity in seawater, cadmium accumulation and subcellular distribution, and growth in polychaetes," Env. Health Perspectives 65, 205-210.

Johns, D. M., Gutjahr-Gobell, R., and Schauer, P. (1985). "Use of bioenergetics to investigate the impact of dredged material on benthic species: A laboratory study with polychaetes and Black Rock Harbor material," Technical Report D-85-7, U.S. Army Engineer Waterways Experiment Station, Vicksburg, MS.

Krone, R. B. (1979). "Sedimentation in the San Francisco Bay system," San Francisco Bay: The urbanized estuary. T. J. Conomos, ed., American Association for the Advancement of Science, San Francisco, CA, 85-96.

Laughlin, R. B., Jr., Ng, J., and Guard, H. E. (1981). "Hormesis: A response to low environmental considerations of petroleum hydrocarbons," Science 211, 705-707.

Lee, R. F. (1988). "Possible linkages between mixed function oxygenase systems, steroid metabolism, reproduction, molting, and pollution in aquatic animals," Offprints from: Toxic contaminants and ecosystem health; A Great Lakes focus. M. S. Evans, ed., John Wiley, New York, 201-213.

Luoma, S. N., and Phillips, D. J. H. (1988). "Distribution, variability, and impacts of trace elements in San Francisco Bay," Mar. Pollut. Bull. $19,413-425$. 
Moore, D. W., and Dillon, T. M. "Chronic sublethal effects of San Francisco Bay sediments on Nereis (Neanthes) arenaceodentata: Nontreatment factors," In preparation, U.S. Army Engineer Waterways Experiment Station, Vicksburg, MS.

Nichols, F. H., Cloern, J. E., Luoma, S. N., and Peterson, D. H. (1986). "The modification of an estuary," Science 231, 567-573.

Pesch, C. E., and Schauer, P. S. (1988). Flow-through culture techniques for Neanthes arenaceodentata (Annelida: Polychaeta), including influence of diet on growth and survival," Environ. Toxicol. Chem. 7, 961-968.

Pesch, C. E., Zajac, R. N., Whitlatch, R. B., and Balboni, M. A. (1987). "Effect of intraspecific density on life history traits and population growth rate of Neanthes arenaceodentata (Polychaeta: Nereidae) in the laboratory," Mar. Biol. 96, 545-554.

Pettibone, M. H. (1963). "Marine polychaete worms of the New England region; 1, Aphroditidae through Trochochaetidae," Smithsonian Institution Museum of Natural History, Washington, DC.

Reish, D. J. (1957). "The life history of the polychaetous annelid Neanthes caudata (delle Chiaje), including a summary of development in the family Nereidae," Pacific Sci. 11, 216-228.

. (1963). "A quantitative study of the benthic polychaetous annelids of Bahia de San Quintin, Baja California," Pacif. Nat. 3, 399-436.

. (1980). "Use of polychaetous annelids as test organisms for marine bioassay experiments," STP 715, Aquatic invertebrate bioassays. A. L. Buikema, Jr., and J. Cairns, Jr., ed., American Society for Testing and Materials, Philadelphia, PA, 140-154.

. (1985). "The use of the polychaetous annelid Neanthes arenaceodentata as a laboratory experimental animal," Tethys 11(3-4), 335-341.

Reish, D. J., and Alosi, M. C. (1968). "Aggressive behavior in the polychaetous annelid family Nereidae," Bull. So. Calif. Acad. Sci. 67(1), 21-28.

Sanders, H. L., Goudsmit, E. M., Mills, E. L., and Hampson, G. E. (1962). "A study of the intertidal fauna of Barnstable Harbor, Massachusetts," Limnol. \& Oceanog. 7(1), 63-79.

Sanders, B., Laughlin, R. B., Jr., and Costlow, J. D, Jr. (1984). "Growth regulation in larvae of the mud crab, Rhithropanopeus harrissii." Crustacean issues, Vol 2: Crustacean growth. A. M. Wenner, ed., A. A. Balkema, Rotterdam. 
Saucier, R. T., Calhoun, C. C., Jr., and Engler, R. M. (1978). "Executive overview and detailed summary of the dredged material research program," Technical Report DS-78-22, U.S. Army Engineer Waterways Experiment Station, Vicksburg, MS.

Stebbing, A. R. D. (1981). "Hormesis-simulation of colony growth in Campanularia flexuosa (Hydrozoa) by copper, cadmium and other toxicants," Aquat. Toxicol. 1, 227-238.

Taghon, G. L., and Greene, R. R. (1990). "Effects of sediment-protein concentration on feeding and growth rates of Abarenicola pacifica Healey et Wells (Polychaeta: Arenicolidae)," J. Exp. Mar. Biol. Ecol. $136,197-216$.

Tam, W. H., Payson, P. D., and Roy, R. J. J. (1986). "Retardation and recovery of growth in brook trout fry (Salvelinus fontinalis) exposed for various durations to acidified water," Can. J. Fish. Aquat. Sci. 43, 2048-2050.

Taylor, J. L. (1984). "Family Nereidae Johnston, 1845." Taxonomic guide to the polychaetes of the northern Gulf of Mexico. Vol V. Chapter 31, J. M. Uebelacker and P. G. Johnson, ed., Barry A. Vittor and Associates, Mobile, AL, 14-15.

Tenore, K. R. (1983). “Organic nitrogen and caloric content of detrititus III. Effect on growth of a deposit feeding polychaete, Capitella capitata," Estuarine, Coastal and Shelf Science 17, 733-742

U.S. Army Corps of Engineers. (1975a). "Dredge disposal study, San Francisco Bay and Estuary; Appendix G: Physical impacts," U.S. Army Engineer District, San Francisco, San Francisco, CA.

. (1975b). “Dredge disposal study, San Francisco Bay and Estuary; Appendix H: Pollutant uptake," U.S. Army Engineer District, San Francisco, San Francisco, CA.

. (1975c). "Dredge disposal study, San Francisco Bay and Estuary; Appendix I: Pollutant availability," U.S. Army Engineer District, San Francisco, San Francisco, CA.

. (1976). "Ecological evaluation of proposed discharge of dredged or fill material into navigable waters. Interim guidance for implementation of Section 404(b) (I) of Public Law 92-500 (Federal Water Pollution Control Act Amendments of 1972)," Miscellaneous Paper D-76-17, U.S. Army Engineer Waterways Experiment Station, Vicksburg, MS.

. (1977). "Dredge disposal study, San Francisco Bay and

Estuary; Main report," U.S. Army Engineer District, San Francisco, San Francisco, CA. 
U.S. Army Corps of Engineers. (1979). “ Dredge disposal study, San Francisco Bay and Estuary; Appendix B: Pollutant distribution," U.S. Army Engineer District, San Francisco, San Francisco, CA.

U.S. Environmental Protection Agency/U.S. Army Corps of Engineers. (1977). "Ecological evaluation of proposed discharge of dredged material into ocean waters. Implementation Manual for Section 103 of Public Law 92-532 (Marine Protection, Research, and Sanctuaries Act of 1972)," U.S. Army Engineer Waterways Experiment Station, Vicksburg, MS.

. (1991). "Evaluation of dredged material proposed for ocean disposal (testing manual). Implementation Manual for Section 103 of Public Law 92-532 (Marine Protection, Research, and Sanctuaries Act of 1972)," U.S. Army Engineer Waterways Experiment Station, Vicksburg, MS.

Weinberg, J. R., Starczak, V. R., Mueller, C., Pesch, G. C., and Lindsay, S. M. (1990). "Divergence between populations of a monogamous polychaete with male parental care: Premating isolation and chromosome variation," Mar. Biol. 107, 205-213.

Weis, P., and Weis, J. S. (1986). "Cadmium acclimation and hormesis in (Fundulus heteroclitus) during fin regeneration," Environ. Res. 39, 356-363.

Whitlatch, P. B. (1977). "Seasonal changes in the community structure of the macrobenthos inhabiting the intertidal sand and mud flats of Barnstable Harbor, Massachusetts," Biol. Bull. 152, 275-294.

Whitlatch, R. B. (1980). "Patterns of resource utilization and coexistence in marine intertidal deposit-feeding communities," J. Mar. Res. 38,743-765.

Widdows, J., Donkin, P., and Evans, S. V. (1987). "Physiological responses of Mytilus edulis during chronic oil exposure and recovery," Mar. Environ. Res. 23, 15-32.

Wilkinson, L. (1988). SYSTAT: The system for statistics. SYSTAT, Inc., Evanston, IL.

Zeitoun, I. H. (1978). "The recovery and hematological rehabilitation of chlorinte stressed adult rainbow trout (Salmo girdneri)," Env. Biol.

Fish. 3(4), 355-359. 


\begin{tabular}{|l|c|c|}
\hline 1. AGENCY USE ONLY (Leave blank) & $\begin{array}{c}\text { 2. REPORT DATE } \\
\text { September } 1993\end{array}$ & $\begin{array}{c}\text { 3. REPORT TYPE AND DATES COVERED } \\
\text { Final report }\end{array}$ \\
\hline
\end{tabular}

4. TITLE AND SUBTITLE

Chronic Sublethal Effects of San Francisco Bay Sediments on Nereis

(Neanthes) arenaceodentata; Interpretative Guidance for a Growth End

Point

6. AUTHOR(S)

David W. Moore, Thomas M. Dillon

5. FUNDING NUMBERS

7. PERFORMING ORGANIZATION NAME(S) AND ADDRESS(ES)

U.S. Army Engineer Waterways Experiment Station

Environmental Laboratory

3909 Halls Ferry Road, Vicksburg, MS 39180-6199
8. PERFORMING ORGANIZATION REPORT NUMBER

Miscellaneous Paper D-93-5

9. SPONSORING/MONITORING AGENCY NAME(S) AND ADDRESS(ES)

10. SPONSORING/MONITORING AGENCY REPORT NUMBER

U.S. Army Corps of Engineers, Washington, DC 20314-1000;

U.S. Army Engineer District, San Francisco, 211 Main Street,

San Francisco, CA 94105-1905

11. SUPPLEMENTARY NOTES

Available from National Technical Information Service, 5285 Port Royal Road, Springfield, VA 22161.

12a. DISTRIBUTION / AVAILABILITY STATEMENT

12b. DISTRIBUTION CODE

Approved for public release; distribution is unlimited.

13. ABSTRACT (Maximum 200 words)

Growth in the polychaete worm Nereis (Neanthes) arenaceodentata has been suggested as a good sublethal end point for marine sediment bioassays. While growth is biologically important, eventual population success is more directly dependent on survival and reproduction. Growth may affect population success indirectly via survival and reproduction. To provide interpretative guidance for bioassays measuring worm growth, the quantitative relationship between growth and reproduction must be established. Juvenile $N$. arenaceodentata were exposed to five geometrically decreasing food rations. Growth, as individual worm wet weight, was measured after 3,6, and 9 weeks. A significant gradient in worm growth was observed at each time interval. Eggs were first observed in the coelom of female worms at the 6-week interval. Subsequent reproduction, measured as fecundity and number of juveniles produced, closely mirrored the reduced growth rates. Based on results reported herein, a somatic growth rate $\geq 0.65 \mathrm{mg} /$ day measured between 0 to 6 weeks resulted in no significant effect on either survival or reproduction. Growth rates $\leq 0.45 \mathrm{mg} /$ day resulted in significant reductions in reproduction. Low growth rates $(0.05 \mathrm{mg} / \mathrm{day})$ were associated with a nearly complete cessation of reproduction and very poor survival (5 to 11 percent). The importance of distinguishing somatic growth from gametic growth in chronic sublethal sediment bioassays with $N$. arenaceodentata is discussed.

\begin{tabular}{|c|c|c|c|}
\hline \multirow{2}{*}{$\begin{array}{l}\text { 14. SUBJECT TERMS } \\
\text { Bioassay } \\
\text { Growth } \\
\text { Neanthes }\end{array}$} & \multirow{2}{*}{$\begin{array}{l}\text { Reproduction } \\
\text { Sublethal }\end{array}$} & & \multirow{2}{*}{$\begin{array}{l}\text { 15. NUMBER OF PAGES } \\
38 \\
16 . \text { PRICE CODE }\end{array}$} \\
\hline & & & \\
\hline $\begin{array}{l}\text { 17. SECURITY CLASSIFICATION } \\
\text { OF REPORT } \\
\text { UNCLASSIFIED }\end{array}$ & $\begin{array}{l}\text { 18. SECURITY CLASSIFICATION } \\
\text { OF THIS PAGE } \\
\text { UNCLASSIFIED }\end{array}$ & $\begin{array}{l}\text { 19. SECURITY CLASSIFICATION } \\
\text { OF ABSTRACT }\end{array}$ & 20. LIMITATION OF ABSTRACT \\
\hline
\end{tabular}

